\title{
A positive theory of the earnings relationship of unemployment benefit
}

\author{
Laszlo Goerke • Markus Pannenberg • \\ Heinrich W. Ursprung
}

\begin{abstract}
In a wage bargaining model, a stronger earnings relationship of unemployment benefit may reduce wages. Therefore, the benefi structure significantl influence profit and trade union utility, raising the question as to how the benefi structure is determined in the political process. We consider a government that chooses the earnings relationship in order to maximize its political support. Our model predicts a strong earnings relationship under right-wing governments and a weak relationship when unions are influential Using panel data for 19 OECD countries, we f nd support for these theoretical predictions. Moreover, we show that the earnings relationship varies negatively with openness.
\end{abstract}

Keywords Earnings relationship · Panel data · Political support maximization · Wage bargaining · Unemployment benefit

JEL Classificatio D72 $\cdot \mathrm{J} 51 \cdot \mathrm{J} 65$

\section{Introduction}

Unemployment insurance benefit vary greatly across countries, both with respect to their structure and their level. In addition, the rules governing unemployment insurance (UI) are frequently changed. This variety indicates that the design of the UI system is the product of a fairly unconstrained political process. While the political-economic determinants of unemployment benefit are fairly well known, the factors shaping the maximum duration of UI payments, the linkage between previous income and benefi levels, and the pertinent

L. Goerke $(\bowtie)$

University of Tübingen, Tübingen, Germany

e-mail: Laszlo.Goerke@uni-tuebingen.de

M. Pannenberg

DIW Berlin, University of Applied Sciences Bielefeld, Bielefeld, Germany

H.W. Ursprung

University of Konstanz, Konstanz, Germany 
eligibility conditions are less understood. These structural components of an UI system are, however, of great importance for the labor market consequences of unemployment benefits

In this paper, we investigate the political-economic determinants of the earnings relationship of UI benefits The earnings relationship is a highly visible, politically sensitive component of UI systems, which changes the payoffs received by the directly affected interests in a predictable manner. Moreover, comparable data are available for OECD countries over a long time period. Analyzing the earnings relationship of UI benefit thus improves our understanding of a fundamental feature of the welfare state, and the availability of high quality data allows us to empirically test the hypotheses that we derive from our politicaleconomic model.

Examples for changes in the linkage between previous incomes and benefit abound: in the UK, under a conservative government, the so-called earnings-related supplement was abolished in 1980. As a consequence, UI benefit became unrelated to previous earnings. In Finland, under the reign of a broad coalition-government, the earnings-related component of unemployment compensation was raised for all unemployed individuals in 2002 and increased further for a subgroup in the next year. In Germany, under a left-wing government, the earnings-related component of "unemployment assistance" (i.e., UI benefit for the long-term unemployed) was replaced by a flat-rat system in 2005. Accordingly, unemployed workers with high previous wages were made worse off, while those with low previous incomes tended to profi (Eichhorst et al. 2006). In Finland, the reform seems to have benefite workers (Uusitalo and Verho 2007), whereas in the UK, the abolition of the earnings-related supplement was generally perceived as a cut in benefit (Atkinson and Micklewright 1989).

The anecdotal evidence outlined above gives rise to the question as to why the earnings relationship of UI benefit is higher in some countries than in others and whether the political orientation of the government influence the choice. In addition to investigating this, we consider how the structure of the welfare state, proxied by the relation between previous earnings and UI benefits will be affected by international economic integration. To provide answers to the above questions, we f rst establish the link between the earnings relationship of UI benefit and labor market outcomes in a unionized economy (Sect. 2), showing in particular that a higher earnings relationship will reduce wages if trade unions maximize the employees' bargaining surplus. Second, we analyze how a political-support maximizing government chooses the earnings relationship (Sect. 3). By assuming a given level of benefits we focus on the benefi structure. Holding constant the level of unemployment compensation is clearly counterfactual, given the policy changes mentioned above. However, the assumption allows us to isolate the impact resulting from a change in the earnings relationship of benefit and to analytically separate it from variations in the level of generosity of the UI system. In our analysis, the earnings relationship of UI benefit therefore constitutes the choice variable of the government. ${ }^{1}$ In adopting this focus, our analysis complements studies on the political economy examining the level of unemployment compensation. Following this section, our theoretical investigation in Sect. 4 indicates that trade unions and left-wing governments favor a relatively low earnings relationship. This is because a more pronounced earnings relationship can reduce the trade union's payoff. International integration also has an impact, particularly because product market competition reduces scope for collective negotiations. The empirical part of our analysis then follows in Sects. 5 and 6. Using data from

\footnotetext{
${ }^{1}$ As mentioned above, governments can not only alter the level of unemployment benefit but often also change, for example, eligibility conditions or the duration of payments. Our analysis takes these components of the overall structure of the UI system as given.
} 
the OECD's Database on Benefit Entitlements and Gross Replacement Rates for 19 countries for the period 1961 to 2003, we fin that the domestic factors that we identifie in our model do indeed have the predicted impact on the earnings relationship. Moreover, the empirical analysis shows that the earnings relationship varies negatively with openness of the economy. Our empirical investigation, based on gross replacement rates, is complemented by an examination that uses net replacement rates for the much shorter period 2001-2006 (for which data is also available). The results based on net replacement rates corroborate the finding obtained for the gross rates.

\subsection{The related literature}

By highlighting a new aspect of unemployment compensation schemes, our paper extends and complements the existing literature on the political economy of UI policy. A large part of this literature makes use of voting models. The early study by Wright (1986) analyzes the individual incentives to establish UI and shows that less than full coverage is chosen by the (employed) median worker. Atkinson (1990) provides similar results, whereas SaintPaul (1996) introduces a richer model, distinguishing four channels by which variation in UI benefit can affect the median voter: wage formation, unemployment risk, labor market turnover, and taxation. Saint-Paul (1996) points out that the wage formation impact which may dominate the other effects is absent in Wright's analysis. Pallage and Zimmermann (2001), Dur (2001), and Hassler et al. (2005) extend the basic voting model in different directions. Boeri et al. (2003, 2004), Blanchard and Tirole (2008), Neugart (2008), and Anesi and De Donder (2009) investigate the joint determination of employment protection and the level of UI in various types of political-economic models. Boeri et al. (2006) show that greater redistribution from high- to low-skilled individuals (which they interpret as a stronger earnings relationship of UI benefits reduces employment protection in equilibrium. Di Tella and MacCulloch (2002) assume that benefit are not the result of a direct vote, but are determined by the government in order to maximize its political support. In contrast to the median voter framework, political-support maximization allows for the impact of the government's political orientation. Di Tella and MacCulloch (2002) show that greater political weight of firm in the political support function can reduce benefits This suggests that the level of UI is higher under left-wing governments. Neugart (2005) explains why countries with majoritarian electoral systems have lower replacement rates than countries with proportional systems. Finally, Vaubel (2008) investigates the general increase in labor market regulations that have been imposed since the introduction of qualifie majority voting in the EU.

Empirical investigations of the determinants of UI benefit generally employ the OECD's Database on Benefit Entitlements and Gross Replacement Rates. Di Tella and MacCulloch (2002) fin some evidence that right-wing governments are associated with lower UI benefits Gaston and Nelson (2004) observe that benefit rise with union density, a left-wing orientation of the government, and the openness of the economy, while Saint-Paul (1996) is unable to identify an impact resulting from the government's political orientation. Using a different data set, Botero et al. (2004) establish a positive association between union density and the generosity of a country's social security system (including UI benefits for a sample of 85 countries. Potrafke (2009) empirically investigates Boulhol's (2009) hypothesis (based on the political-support maximization approach) that capital mobility and trade liberalization trigger labor market deregulation. Potrafke (2009) does indeed fin that labor market deregulation is associated with globalization; however, the most significan driving force appears to be the change in people's attitudes in the course of globalization. 
The literature on earnings-related UI benefit has dealt primarily with the economic consequences of altering the replacement rate. Lingens and Wälde (2009) show that a higher replacement rate generally increases unemployment in models of collective wage determination, irrespective of the nature of the benefi system. A change in the replacement rate can, of course, be decomposed into a variation in the level of benefit and a change in the earnings relationship. Focusing on the latter, that is, holding the level of UI benefit constant, Vijlbrief and van de Wijngaert (1995) show that a stronger earnings relationship increases unemployment in an economy with utilitarian trade unions. Goerke and Madsen (2003) obtain the reverse prediction for a model in which the trade union maximizes the benefit of employed workers from employment at the union wage. The intuition is that any increase in the unemployed workers' payoffs reduces the gain enjoyed by the employed union members. Beissinger and Egger (2004), assuming a similar objective as Goerke and Madsen (2003), do show that a higher earnings-related replacement rate has a positive employment effect in a dynamic wage bargaining framework. Heer and Morgenstern (2005) assume that workers who become unemployed either obtain UI benefit or fin a job in another sector of the economy; showing that a higher earnings relationship raises employment. In sum, there is substantial evidence that the earnings relationship of UI benefit moderates a trade union's wage claims. This negative relationship can also be obtained in a search and matching framework (Heer and Morgenstern 2005) and in an efficien y wage model with continuous effort decision (Goerke 2001). Finally, Heer (2006) analyzes a greater earnings relationship of short-term UI benefit at the expense of lower flat-rat long-term payments, using a calibrated general equilibrium overlapping-generations model with variable labor supply. While the effects are quantitatively small, employment tends to rise.

Our own analysis builds on the studies of the labor market effects of earnings-related UI benefit and tackles the issues which have been investigated in the existing politicaleconomic literature with respect to the level of UI benefits Using the established politicalsupport maximization approach, we ask what determines the earnings relationship of UI benefits and whether the respective theoretical predictions are consistent with the empirical evidence?

\section{The economic sector}

Consider an economy consisting of two sectors $j, j=\mathrm{s}$, e. In the sheltered sector s, nontradable goods are produced, which have a constant price $p^{\mathrm{s}}$. In the exposed sector e, tradable goods are manufactured. Their price is $p^{\mathrm{e}}$. The consumer price (index) is given by $p$ and is increasing linearly with both prices $p^{\mathrm{s}}$ and $p^{\mathrm{e}}$. Wages are determined by firm-l vel collective bargaining. ${ }^{2}$ There are many identical firm in each sector and one trade union per firm The number of $\mathrm{frms}$ and, therefore, also the number of unions is constant. Labor is assumed to be sector specific Profit $\pi^{\mathrm{s}}$ per (representative) sheltered sector fir consist of the price times output less labor costs, $\pi^{\mathrm{s}}=p^{\mathrm{s}} f\left(n^{\mathrm{s}}\right)-w^{\mathrm{s}} n^{\mathrm{s}}$, where $f$ is an increasing and strictly concave production function $\left(f^{\prime}>0, f^{\prime \prime}<0\right), n^{\mathrm{s}}$ the level of employment, and $w^{\mathrm{s}}$ the wage. By analogy, profit of a representative fir in the exposed sector are $\pi^{\mathrm{e}}=p^{\mathrm{e}} f\left(n^{\mathrm{e}}\right)-w^{\mathrm{e}} n^{\mathrm{e}}$. Each fir bargains with 'its' union over the wage and then sets employment at the level

\footnotetext{
${ }^{2}$ Although gross union density varied between $8.3 \%(8.6 \%)$ in France and $80.1 \%(76 \%)$ in Sweden in 2000 (2005), bargaining coverage is substantially higher than density. The (unweighted) collective bargaining coverage amounted to $60 \%$ in the OECD and to $68.8 \%$ in the European Union (EU 15) in 2000. However, coverage reached or even exceeded 90\% in numerous countries (OECD 2004; European Commission 2008). Assuming collective negotiations is therefore a good approximation for most OECD countries.
} 
$n^{j}\left(w^{j}, p^{j}\right)$. The only linkage between the two sectors is via the consumer price $p$. Accordingly, most of the subsequent analysis focuses on one sector and the finding can be generalized to the entire economy. However, since we will also analyze the effect of greater openness of the economy, we already introduce the exposed sector at this stage.

A trade union can be utilitarian and maximize the sum of its members' utility. Alternatively, it can be insider-dominated, maximizing its members' benefit (or rent, if risk-neutral) from employment at the union wage. Which of these two objectives prevails is an open empirical issue (Oswald 1982, 1993; Pencavel 1991, pp. 54, 81-92; and Booth 1995, pp. 87, 101-108). Therefore, we assume that unions of either type may be present in each sector. Let the fraction $\lambda^{j}, 0 \leq \lambda^{j} \leq 1$, of all trade unions in sector $j$ be utilitarian and the fraction $\left(1-\lambda^{j}\right)$ be insider-dominated. Each union has an exogenously given number of $M^{j}$ members, of which $n^{j}, n^{j} \leq M^{j}$, are employed. A member can be characterized by a strictly concave (indirect) utility function $v(\cdot), v^{\prime}>0, v^{\prime \prime}<0$, where $v$ is a function of real income. The $n^{j}$ employed members earn the wage $w^{j}$, and thus enjoy the utility $v\left(w^{j} / p\right)$. The remaining $M^{j}-n^{j}$ members obtain real UI benefit amounting to $B^{j} / p$.

Nominal UI benefit $B^{j}$ consist of a (sector-specific fxed component $a^{j}, a^{j}>0$, and an income dependent component $c w^{j}, c \geq 0$, implying $B^{j}=a^{j}+c w^{j}$. UI benefit are usually independent of the wage for those unemployed workers who were already without a job before wage determination took place. This is the case since earnings-related benefit are a function of past income. The alternative income of workers who lose their jobs because of higher (real) wages will, however, be affected by the strength of the earnings relationship, since their benefit are based on the new wage. Capturing these differential effects requires an explicitly dynamic approach. To circumvent this analytical extension, the income when not working at the union wage is assumed to be unemployment compensation.

The objective of a utilitarian trade union (indexed by $u$ ) in sector $j$ is given by:

$$
U^{u, j}=n^{j}\left(w^{j}, p^{j}\right)\left[v\left(\frac{w^{j}}{p}\right)-v\left(\frac{B^{j}}{p}\right)\right]+M^{j} v\left(\frac{B^{j}}{p}\right) .
$$

The objective of an insider-dominated trade union (indexed by $i$ ) in sector $j$ equals:

$$
U^{i, j}=n^{j}\left(w^{j}, p^{j}\right)\left[v\left(\frac{w^{j}}{p}\right)-v\left(\frac{B^{j}}{p}\right)\right] .
$$

To analyze aggregate union behavior, we make use of an 'average' union utility function $U^{j}$ :

$$
U^{j}=\lambda^{j} U^{u, j}+\left(1-\lambda^{j}\right) U^{i, j}=n^{j}\left(w^{j}, p^{j}\right)\left[v\left(\frac{w^{j}}{p}\right)-v\left(\frac{B^{j}}{p}\right)\right]+\lambda^{j} M^{j} v\left(\frac{B^{j}}{p}\right) .
$$

The outcome of wage negotiations is determined by the Nash-solution. Both parties are endowed with the same bargaining power. The fi ed fallback payoffs are determined by the no agreement outcome and normalized to zero. Given firm-l vel bargaining, the wage negotiated in a particular union-fir pair equals the sector-specifi wage. In the sheltered sector s, maximization of the Nash-product $U^{\mathrm{s}} \pi^{\mathrm{s}}$ with respect to the wage and definin $\varepsilon^{\mathrm{s}}:=$ $\left(\partial n^{\mathrm{s}} / \partial w^{\mathrm{s}}\right)\left(w^{\mathrm{s}} / n^{\mathrm{s}}\right)<0, v:=v\left(w^{\mathrm{s}} / p\right)$ and $\bar{v}:=v\left(B^{\mathrm{s}} / p\right)$, yields (2.4), where we assume an interior solution:

$$
K^{\mathrm{s}}:=\left(\varepsilon^{\mathrm{s}}(v-\bar{v})+w^{\mathrm{s}} v^{\prime}-w^{\mathrm{s}} \bar{v}^{\prime} c\left(1-\lambda^{\mathrm{s}} \frac{M^{\mathrm{s}}}{n^{\mathrm{s}}}\right)\right) \pi^{\mathrm{s}}-\left\{n^{\mathrm{s}}(v-\bar{v})+\lambda^{\mathrm{s}} M^{\mathrm{s}} \bar{v}\right\} w^{\mathrm{s}}=0 .
$$

The firs bracketed term is proportional to the union's marginal gain from bargaining and will be positive if $K^{\mathrm{s}}=0$ holds, since the expression in curly brackets in (2.4) is greater than zero. The second-order condition $\partial K^{\mathrm{s}} / \partial w^{\mathrm{s}}<0$ is assumed to hold (see Appendix A.1). 
Suppose now that the government changes the structure of UI benefit by raising the earnings-related element and lowering the flat-rat component, while holding constant the respective levels $B^{\mathrm{e}}$ and $B^{\mathrm{s}}$. Taking the sheltered sector as an example again, such a policy requires an increase in the parameter $c$ and a change in the fxed component $a^{\mathrm{s}}$, so that $\mathrm{d} B^{\mathrm{s}}=\mathrm{d} a^{\mathrm{s}}+w^{\mathrm{s}} \mathrm{d} c+c \mathrm{~d} w^{\mathrm{s}}=0$ holds, where the change in the wage $w^{\mathrm{s}}$ will be non-zero if the bargaining outcome is affected by the variation in the structure of benefits From (2.4), we have

$$
\left.\frac{\partial w^{\mathrm{s}}}{\partial c}\right|_{\mathrm{d} B^{\mathrm{s}}=0}:=w_{c}^{\mathrm{s}}=\frac{\Psi \pi^{\mathrm{s}} w^{\mathrm{s}} \bar{v}^{\prime}}{\frac{\partial \bar{K}^{\mathrm{s}}}{\partial w^{\mathrm{s}}}(v-\bar{v})}\left(1-\frac{\lambda^{\mathrm{s}} M^{\mathrm{s}}}{n^{\mathrm{s}}}\right),
$$

where $\partial \bar{K}^{\mathrm{s}} / \partial w^{\mathrm{s}}<\partial K^{\mathrm{s}} / \partial w^{\mathrm{s}}<0\left(\partial \bar{K}^{\mathrm{s}} / \partial w^{\mathrm{s}}\right.$ is the change in $K^{\mathrm{s}}$ due to a rise in the wage, evaluated at a constant level of benefits see Appendix A.1. Thus, a stronger earnings relationship of benefit will reduce the bargained wage if the fraction $\lambda^{\mathrm{s}}$ of utilitarian unions is less than the ratio of employment $n^{\mathrm{s}}$ to membership $M^{\mathrm{s}}$. This restriction is captured by

$$
1-\frac{\lambda^{\mathrm{s}} M^{\mathrm{s}}}{n^{\mathrm{s}}}>0 \quad(\text { Condition } \mathrm{C}) \text {. }
$$

Given an unemployment rate of substantially less than $20 \%$ in most industrialized countries, which implies that $M^{\mathrm{s}} / n^{\mathrm{s}}<1.25$, Condition $\mathrm{C}$ will definitel be satisfie if the number of utilitarian unions relative to insider-dominated unions is not greater than 4 to 1 , i.e., if $\lambda^{\mathrm{s}}<0.8$. We will take this assumption as a point of departure in the following investigation. Since the analysis for the sheltered sector carries over to the exposed sector, the employment performance of an economy locally improves when the earnings relationship of UI benefit increases in strength (assuming a given level of unemployment compensation).

The intuition for the negative wage effect of a stronger earnings relationship of benefit is the following: the Nash-solution prescribes how the gains from bargaining are shared between the union and the firm The rise in profit is unaffected by a change in the earnings relationship. However, the union's gain from bargaining will be reduced if Condition C holds, since the increase in the payoff owing to a higher wage is lower for any given wage and benefi level; that is, the firs term in brackets in (2.4) shrinks. Accordingly, any wage increase induces a more pronounced expansion in benefit than before the rise in $c$. Therefore, a given increase in the wage induces a smaller gain for the union than before the change in $c$. Hence, the efficien y requirement of the Nash-solution implies that wages fall.

\section{The political sector}

The government maximizes a political support function $S$ which contains the unions' utilities and the frms' profit in both sectors as arguments. ${ }^{3}$ The weights for aggregate trade union utility and aggregate profit are denoted by $\alpha$ and $1-\alpha, 0<\alpha<1$. The weight of unions (firms in the sheltered sector relative to that in the exposed sector is $\beta_{\mathrm{U}}\left(\beta_{\mathrm{F}}\right)$. The fi ed number of firm is normalized to unity. As mentioned in Sect. 1, the choice variable of the government is the earnings relationship of UI benefit $c$, while the levels $B^{\mathrm{s}}$ and $B^{\mathrm{e}}$ are given. We assume that the government can commit to its choice of $c$ and, as a Stackelbergleader, takes into account the resulting wage and employment effects. This sequence of decisions reflect the fact that wage negotiations generally occur annually or bi-annually (Du Caju et al. 2008), whereas replacement rates change more slowly over time (OECD 2007).

\footnotetext{
${ }^{3}$ See Boulhol (2009) for a similar political-support maximization model.
} 
Maximizing $S$ with respect to $c$ and holding constant the level of benefit implicitly define the earnings relationship $c^{*}$ of UI benefit that maximizes the government's political support:

$$
S_{c}:=\left.\frac{\mathrm{d} S}{\mathrm{~d} c}\right|_{\mathrm{d} B^{\mathrm{s}}=\mathrm{d} B^{\mathrm{e}}=0}=\alpha\left[\beta_{\mathrm{U}} U_{c}^{\mathrm{s}}+U_{c}^{\mathrm{e}}\right]+(1-\alpha)\left[\beta_{\mathrm{F}} \pi_{c}^{\mathrm{s}}+\pi_{c}^{\mathrm{e}}\right]=0 .
$$

The second-order condition $S_{c c}<0$ is assumed to be satisf ed. ${ }^{4}$ Evaluated at the bargained wage and given Condition $\mathrm{C}$, the respective terms in (3.1) are given by

$$
\begin{aligned}
& U_{c}^{j}:=\left.\frac{\partial U^{j}}{\partial c}\right|_{\mathrm{d} B^{j}=0}=\frac{\partial U^{j}}{\partial w^{j}} w_{c}^{j}=n^{j} w_{c}^{j} \frac{\varepsilon^{j}(v-\bar{v})+w^{j} v^{\prime}}{w^{j} p}<0, \\
& \pi_{c}^{j}:=\left.\frac{\partial \pi^{j}}{\partial c}\right|_{\mathrm{d} B^{j}=0}=-n^{j} w_{c}^{j}>0 .
\end{aligned}
$$

A union's utility decreases with a greater earnings-sensitivity of UI benefit for two reasons: first the negotiated wage is too low from the union's point of view (cf. (2.4)), owing to the firm s impact on the bargaining outcome. Therefore, a reduction in wages due to a stronger earnings relationship takes the union further from its optimal position. Second, a higher earnings relationship will reduce the trade union's gain from a given wage increase. This is the case since the impact of the wage on UI benefit rises. In contrast, a fir benefit from a stronger earnings relationship because wages fall, thus raising profits The government balances these counteracting influence at the margin. Since the changes in payoffs will only occur if the earnings relationship alters wages, our result represents a further example of the importance of the wage formation effect, as emphasized by Saint-Paul (1996).

\section{Determinants of the earnings relationship}

As outlined in the Introduction, the political support-maximizing earnings relationship $c^{*}$ may be affected by domestic factors, such as the political orientation of the government or the political influenc of trade unions and firms and also by international economic integration. Thus, a change in $c^{*}$ over time or across countries can be explained, for example, by an increase in the power of trade unions as compared to that of firms i.e., in the fina analysis, by a greater impact of employees relative to the influenc exerted by owners of firms ${ }^{5}$ Greater weight of trade unions in the political support function is portrayed in our model by a higher value of $\alpha$.

$$
\frac{\partial c^{*}}{\partial \alpha}=-\frac{S_{c \alpha}}{S_{c c}}=-\frac{\beta_{\mathrm{U}} U_{c}^{\mathrm{s}}+U_{c}^{\mathrm{e}}-\left(\beta_{\mathrm{F}} \pi_{c}^{\mathrm{s}}+\pi_{c}^{\mathrm{e}}\right)}{S_{c c}}<0
$$

\footnotetext{
${ }^{4}$ If the impact of the earnings relationship does not differ across sectors and the firm s and union's weights in the sheltered sector are the same $\left(\beta_{\mathrm{U}}=\beta_{\mathrm{F}}\right),(3.1)$ - using (3.2) - can be rewritten as $\alpha U_{c}^{j}+(1-\alpha) \pi_{c}^{j}=$ $n^{j} w_{c}^{j}\left\{\alpha\left[\varepsilon^{j}(v-\bar{v})+w^{j} v^{\prime}\right] /\left(w^{j} p\right)-1+\alpha\right\}=0$. Since the term in curly brackets is zero, while $w_{c}^{j}<0$ results from (2.5), given Condition $\mathrm{C}$ and a constant labour demand elasticity $\varepsilon^{j}, S_{c c}<0$ will hold if $\varepsilon^{j}\left[w^{j} v^{\prime}-\right.$ $(v-\bar{v})]+v^{\prime \prime}\left(w^{j}\right)^{2}<0$. If, in contrast to our above assumption of the government being a Stackelberg-leader, the earnings relationship $c$ were determined simultaneously with or subsequent to the wage, the value of $c$ would not affect bargaining and the government's political support would be independent of $c$.
}

${ }^{5}$ See Di Tella and MacCulloch (2002), Saint-Paul (1996) and Gaston and Nelson (2004) for corresponding hypotheses with respect to the determinants of the level of benefits 
Expression (4.1) then gives rise to:

Prediction 1 For a given level of unemployment compensation and assuming that Condition $\mathrm{C}$ holds, greater political influenc of the trade unions reduces the earnings relation$\operatorname{ship} c^{*}$ of UI benefits

The parameter $\alpha$ may also reflec the political orientation of the government. If a more right-wing or conservative government places less emphasis on workers' interests, a lower value of $\alpha$ can also indicate a more right-wing government. We therefore obtain the following prediction.

Prediction 2 For a given level of unemployment compensation and assuming that Condition $\mathrm{C}$ holds, a right-wing government chooses a stronger earnings relationship $c^{*}$ of UI benefit than a left-wing government.

The effects summarized in Predictions 1 and 2 occur because an increase in the earnings relationship, for a given level of UI benefits will reduce the bargained wage if the share of utilitarian unions is not too high. Since lower wages reduce the trade unions' payoffs, a greater political influenc of unions or their political representatives will induce the government to lower the earnings relationship. If, however, Condition $\mathrm{C}$ does not hold, the bargained wage will rise with the earnings relationship of UI benefits No attempt has yet been made to determine the fraction of utilitarian trade unions. Findings by Goerke and Madsen (2003) for 16 OECD countries suggest that wages and the earnings relationship of UI benefit are negatively correlated. This result is consistent with Condition $\mathrm{C}$ and Predictions 1 and 2.

Recent decades have not only seen repeated changes in government ideology in many if not most OECD countries, but also a deepening of international economic integration, resulting in stronger competition on goods and factor markets. In terms of our model, increased international competition can be interpreted as an increase in the political importance, or, alternatively, as an expansion in the size of the exposed sector. Both effects reduce the political weights $\beta_{\mathrm{F}}$ and $\beta_{\mathrm{U}}$ of firm and trade unions in the sheltered sector. Since the payoffs of unions and f rms vary inversely with the earnings relationship of benefits a rise in the political importance of the exposed sector has ambiguous effects on the optimal value $c^{*}$.

A deepening of international economic integration, particularly via an increase in international factor mobility, enhances the mobility of firm across jurisdictions, and thus raises their political influenc (see, for example, Gaston and Nelson 2004). In our model, this mechanism is not explicitly portrayed since the number of $\mathrm{frms}$ is fxed. If globalization is viewed in such a manner, we can nevertheless indirectly integrate this interpretation into the above setting by assuming that greater international integration induces a decline in the political importance of trade unions. This will raise the earnings relationship of UI benefit (cf. Prediction 1). Finally, international integration can also give rise to a more competitive environment in the exposed sector. It is shown in Appendix A.2 that the ensuing reduction in the price of tradable goods can lower the earnings relationship $c^{*}$. Thus, we have the following prediction.

Prediction 3 A change in the international integration of an economy affects the political support-maximizing earnings relationship $c^{*}$ of UI benefits

Our theoretical considerations suggest a rather complex relationship between the openness of an economy and the earnings relationship of UI benefits Unfortunately, the (joint) 
consequences of a larger exposed sector, greater weight of firms and price reductions for tradable goods cannot be determined. Thus, the expected impact of globalization on the earnings relationship of UI benefit is ambiguous and remains, ultimately, an empirical issue.

\section{Data, variables and empirical specification}

\subsection{Data and variables}

Our dependent variable is a measure of the earnings relationship c of UI benefits Even though $c$ is not directly observable, it can be calculated on the basis of information from the OECD's Database on Benefit Entitlements and Gross Replacement Rates. This database provides information on gross replacement rates (RR) for average production workers (denoted $\mathrm{RR}_{100}$ ) and workers earning two-thirds of the income of average production workers $\left(\mathrm{RR}_{67}\right)$. The replacement rates include unemployment insurance, unemployment assistance, and social welfare payments, as well as housing and family benefits This data is available on a biannual basis and we use information for the period 1961 to $2003 .{ }^{6}$ The values of $\mathrm{RR}_{100}$ and $\mathrm{RR}_{67}$ are available for different durations of unemployment $(0-3,4-6,7-12,13-24$, 25-36, 37-48 and 49-60 months and as unweighted summary measures for the firs year, second and third year and fourth and fift year) as well as for three different categories of workers (single persons, persons with a dependent spouse without employment, and persons with an employed spouse).

Using measures of $\mathrm{RR}_{100}$ and $\mathrm{RR}_{67}$ for different durations of unemployment helps to disentangle the effects of different sources of payments. For short durations, financia compensation is likely to stem primarily from UI benefits while for longer unemployment periods, the most important component may rather consist of social assistance. The respective measures $\mathrm{RR}_{100} d$ and $\mathrm{RR}_{67} d$ for different durations $d$ of unemployment are unweighted averages of the replacement rates for the three categories of workers.

For each unemployment duration, the earnings relationship of benefit is calculated in the following way: assuming a linear relation between benefit and earnings, unemployment compensation of a $\mathrm{RR}_{100}$ person is define as $w \cdot \mathrm{RR}_{100}=a+c \cdot w$, w being the wage of an average production worker prior to unemployment. For a $\mathrm{RR}_{67}$ person, we have $0.67 \cdot w$. $\mathrm{RR}_{67}=a+0.67 \cdot c \cdot w$. From these two definitions the measure $c$ for each unemployment duration $d$ can easily be calculated as

$$
c \_d=3 \mathrm{RR}_{100 \_} d-2 \mathrm{RR}_{67} d \text {. }
$$

We also construct summary measures of the earnings relationship $c \_$all and of the replacement rate RR_all as an unweighted average over all durations, income levels, and categories of workers. Figure 1 contains plots of these summary measures $c$ _all of the earnings relationship over the whole time period (1961-2003) for all 19 countries included in our sample. ${ }^{7}$

\footnotetext{
${ }^{6}$ See OECD (2007) and Martin (1996). An average production worker (APW) is define as an adult full-time production worker in the manufacturing sector with average earnings. Since 2007, the OECD employs the concept of an average worker instead of an APW. Since data for gross replacement rates for average workers are only available for a short time period, we use the information on APWs (see OECD 2007).

${ }^{7}$ The measure $c \_d$ will be negative if actual benefit decline with the previous income. We incorporate negative values of $c_{-} d$, occurring in about $10 \%$ of all cases, into our empirical analysis to avoid any truncation
} 


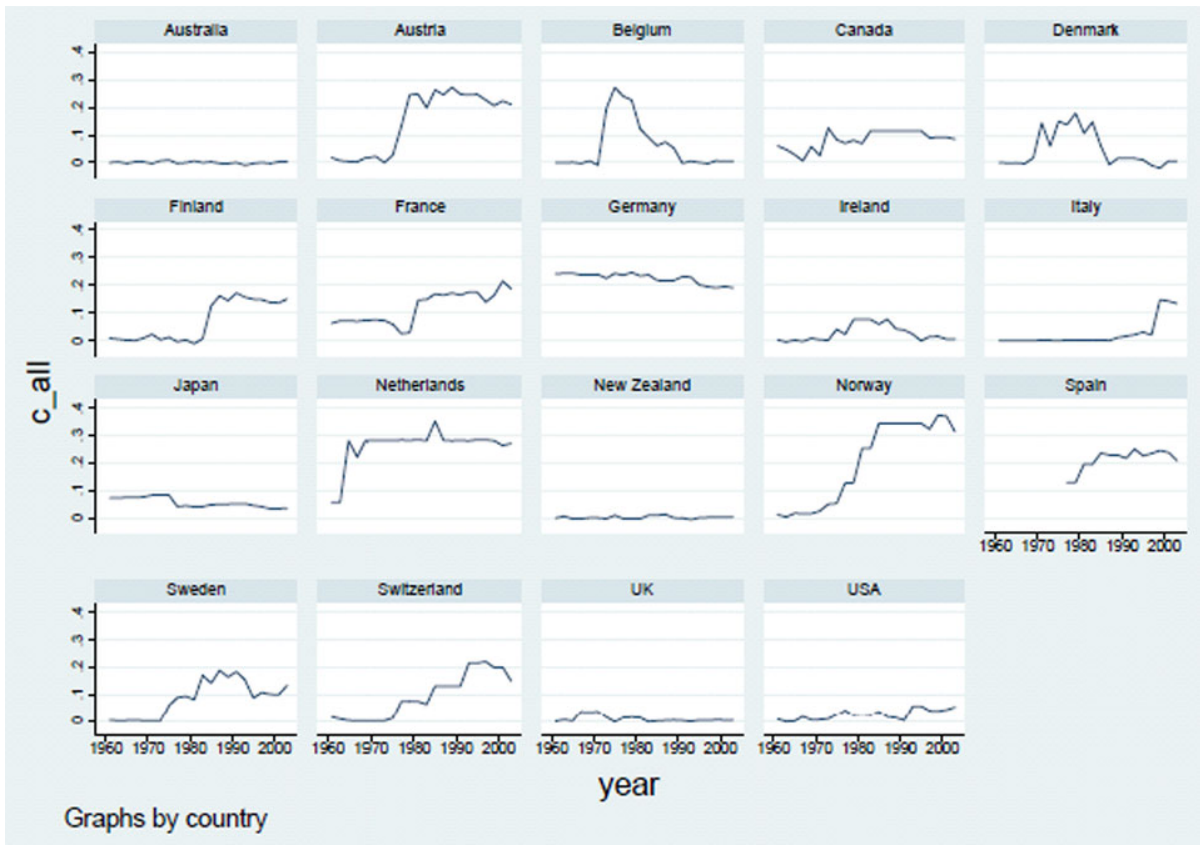

Fig. 1 Summary measure of the earnings relationship $c$ all (1961-2003). Source: Own calculations based on OECD data. See Appendix A.4 for details

The plots reveal a remarkable variation of $c$ over time and across countries. In Norway and Sweden, for example, there is a large increase, starting in the 1970s and lasting until the 1990 s, followed by a (slight) decrease. In Finland, the more pronounced earnings relationship referred to in Sect. 1 is reflecte in the rise of $c \_$all at the end of the observation period. For France, we witness a substantial increase in the 1980s. In Germany, the measure of the earnings relationship is fairly stable over time. Australia, New Zealand, and the UK are characterized by a rather flat-rat unemployment compensation. In the UK, the abolition of the earnings-related supplement at the beginning of the 1980s is (just) discernible. Moreover, there is a great deal of cross-country variation. The summary measure for Norway is, for example, roughly six times larger than in the US in 2003.

The raw correlation coeff cients between the earnings relationships for different durations $d$ decrease as the duration of unemployment increases (see Table 3 in Appendix A.3). This decline suggests that the determinants of the earnings relationship vary significantl over time. Moreover, the unweighted average of the earnings relationship $c$ falls with the length of the unemployment spell, amounting to about 0.27 for durations of less than 6 months and to almost zero for durations exceeding 3 years (see Table 4 in Appendix A.3).

It could be argued (see, for example, Neugart 2005) that the disincentive effects of unemployment compensation are not determined by the gross but the net replacement rates, which measure the net income while unemployed relative to the net income prior to the unemployment spell. In terms of our model, this may be the case because the costs of a job

bias. In the theoretical model, $c \geq 0$ is assumed to simplify the exposition. Figures 2-5 in Appendix A.3-A.4 contain plots of the respective values of the earnings relation for each duration $d$ of unemployment that we use in the estimations. 
loss to the trade union arise from the utility difference between employed and unemployed workers. Since (indirect) utility is a function of disposable income, the relevant difference may be determined by the net replacement rates. However, this view will only be appropriate if taxes and, in particular, social security contributions do not generate entitlements to future payments, such as pensions. Disney (2004), for example, fnds the tax component of contributions to public pensions to be less than $40 \%$ and to vary substantially across OECD member states. As a consequence, it seems desirable to complement the analysis of gross replacement rates with an investigation based on net replacement rates. However, the OECD provides no extensive time series for the latter. Information on net replacement rates is available for at least two income levels, required to compute the measure of the earnings relationship, on an annual basis from 2001 to 2006. Despite this short time period, we will supplement our main analysis based on gross replacement rates by an investigation relying on net rates.

Our measures of the earnings relationship and replacement rate are merged with information on the political influenc of trade unions, the political preferences of the government, the openness of the economy, and labor market tightness. ${ }^{8}$ Prediction 1 states that the earnings relationship of benefit falls with greater political influenc of unions. For the sake of simplicity and adopting the approach employed in most models of collective bargaining, in our theoretical analysis, trade union membership is fi ed and density cannot be less than unity. Nevertheless, in reality, union density is less than complete and the political influenc of trade unions, especially in democracies, can be approximated by the number of its members, relative to employment. Note that the influenc of trade unions is twofold in our model since it is not only present in the political support function but also in the wage setting process. The employment impact of the earnings relationship of UI benefit will be stronger, the more comprehensive the collective negotiations, since the earnings relationship will not affect wages in a competitive labor market. This insight would suggest an indicator of collective-bargaining coverage as a further explanatory variable. However, while bargaining coverage varies substantially over time, no data set with bi-annual measures of bargaining coverage in OECD countries is available for the entire time period. ${ }^{9}$ As a substitute, we employ a measure of the centralization of wage bargaining. In particular, we combine information on aggregate net union density ${ }^{10}$ with time-variant information on the bargaining level at which wages are determined (from "plant-level" to "central wage setting") (BargUD). The hypothesis is that a union with a given net density has, ceteris paribus, a greater political influence the more centralized the wage setting process; as does a trade union characterized by a higher density, for a given degree of centralization.

Prediction 2 states that a right-wing government selects a more pronounced earnings relationship of UI benefits To capture government characteristics, we firs use an updated

\footnotetext{
${ }^{8}$ Descriptive statistics of all variables used in our empirical analysis are given in Appendix A.3, Table 4. Appendix A.4 provides details on data sources, missing values, and the calculation of all variables used in the regression analyses.

${ }^{9}$ Note that even the ICTWSS database (Visser 2009) on which the European Commission (2008) bases its analysis does not contain sufficien information on coverage, since data is interpolated (United Kingdom, New Zealand, Switzerland) or missing entirely for the 1960s (Spain, New Zealand).

${ }^{10} \mathrm{Net}$ union density is define as the number of employed union members relative to the sum of gainfully employed and unemployed individuals. Gross union density incorporates all union members including, for example, students and pensioners, in the numerator. Hence, it could be argued that gross density, too, is an appropriate proxy of the political influenc of trade unions. However, data on gross union densities is available for a shorter period and fewer countries only than that on net densities. Moreover, since the levels of and changes in gross and net densities are highly correlated for those periods and countries for which both are accessible, we use net union densities.
} 
government composition index originally calculated by Cusack (1999). Three groups of governments are distinguished: "left" governments $\left(L_{\mathrm{G}}\right)$ (consisting of social democratic parties and parties to their left), "right" governments $\left(R_{\mathrm{G}}\right)$ (consisting of liberal or conservative parties), and "stalemate" governments $\left(S_{\mathrm{G}}\right)$ (coalitions of parties). This information is included in the form of a dummy variable. Second, we employ a cabinet composition index which measures the percentage of total cabinet posts of "social democratic/other left" parties, "centre" parties, and "right-wing" parties, weighted by the number of days in office This cabinet composition index is multiplied by the "left-right scale" of government composition described above and aggregated across all cabinet parties to obtain a continuous "right-wing" government $\left(\mathrm{RW}_{\mathrm{G}}\right)$ variable as an alternative to the dummy variable specifica tion. ${ }^{11}$

Prediction 3 relates the openness of an economy to the political support-maximizing earnings relationship of UI benefits Following, for example, Agell (2002), Gaston and Nelson (2004), and Gaston and Rajaguru (2008), we use the sum of exports and imports of goods and services as a percentage of GDP to arrive at a proxy for the economy's exposure to foreign trade (Openness).

Since all of our theoretical predictions are conditional on a given level of unemployment compensation, the relevant aggregate level of the gross replacement rate $\left(\mathrm{RR}_{d}\right)$ is also included in our estimation procedures. Finally, we use the unemployment rate (UR) to take country-specifi labor market slack into account.

\subsection{Empirical specification}

Given the nature of our data, we use a linear panel data framework in the empirical analysis. We start with Wooldridge's test for serial correlation (Wooldridge 2002), because serial correlation in linear panel data models biases the standard errors. Since we must reject the null-hypothesis of no serial correlation, the idiosyncratic errors in our empirical specifica tions are modeled as a stationary AR(1) process. We include the contemporaneous level of the gross replacement rate since our theoretical predictions rely on a constant amount of UI benefits This assumption can also be justifie empirically. Using a test of strict exogeneity as suggested by Wooldridge (2002), we cannot reject the null hypothesis that the gross replacement rate is strictly exogenous for any specificatio in our sample. In our model, the product of "bargaining level" and "net union density" (BargUD) as well as the measure of openness might have an impact on the earnings relationship of benefit via the political support function. Therefore, we use lagged values of both variables in our regressions. Furthermore, there is weak evidence that the contemporaneous unemployment rate is not strictly exogenous, using Wooldrige's test of strict exogeneity. To take this into account, we also include lagged values of the unemployment rate. As a consequence of the above considerations, we employ the following specificatio of our linear panel data model for country $i$ and year $t: 12$

$$
\begin{gathered}
c_{i, t \_} d=\alpha_{0}+\alpha_{1} \text { BargUD }_{i, t-1}+\alpha_{2} \text { Openness }_{i, t-1}+\alpha_{3} S_{\mathrm{G} i, t}+\alpha_{4} R_{\mathrm{G} i, t} \\
\quad+\alpha_{5} \mathrm{UR}_{i, t-1}+\alpha_{6} \mathrm{RR}_{i, t \_} d+u_{i}+\eta_{t}+\varepsilon_{i, t} \\
\text { with: } \varepsilon_{i, t}=\rho \varepsilon_{i, t-1}+v_{i, t} \quad \text { and }|\rho|<1, v_{i, t} \operatorname{iid}\left(0, \sigma_{v}^{2}\right)
\end{gathered}
$$

\footnotetext{
${ }^{11}$ This combined variable is similar to the political information employed by Di Tella and MacCulloch (2002).

${ }^{12}$ Based on test statistics of Maddala and Wu's unit root test for panel data for all biannual $c \_d$ variables, we fin no evidence for non-stationarity in our data.
} 
where $c_{i, t_{-}} d$ is the duration-specifi earnings relationship of UI benefits $u_{i}$ is a timeinvariant country effect, $\eta_{t}$ is a fi ed time effect, and the remainder disturbances $\varepsilon_{i, t}$ follow a stationary AR(1) process. All other regressors in (5.2) are define as described above. As a check of robustness, we also estimate a slightly modifie version of (5.2) where we use our continuous "right-wing" government variable $\left(\mathrm{RW}_{\mathrm{G}}\right)$ instead of the two dummy variables $S_{\mathrm{G}}$ and $R_{\mathrm{G}}$. We employ three econometric procedures (see, for example, Baltagi 2005): (1) a Prais-Winston regression with fi ed country effects, fi ed year effects and "panel-corrected standard errors", i.e., the standard errors are assumed to be heteroscedastic, f rst-order autocorrelated within panels with a common $\rho$ and contemporaneously correlated across panels; (2) a within estimator of a two-way fi ed-effects linear panel data model with an AR(1) disturbance; and (3) a random-effects estimator with random country effects, fi ed year effects, and an $\mathrm{AR}(1)$ disturbance.

\section{Results}

The parameter estimates of the two specification for the summary measure $c_{-}$all of the earnings relationship c of UI benefit are shown in Table 1.

The estimates for BargUD, the interaction of net union density and the bargaining level, are always significan and indicate a negative correlation between the summary measure $c \_$all of the earnings relationship and the political power of trade unions. Hence, the greater the political power of the trade union, the lower the earnings relationship of UI benefit (for a given level of unemployment compensation). This is in line with Prediction 1. The size of the estimated effect might be illustrated as follows: in a fictitiou country with a central wage setting system (e.g., Norway) and the mean value of $c_{-}$all, a 10 percentage point decrease in net union density induces, ceteris paribus, a $4.5 \%$ increase in the earnings relationship.

The parameter estimates of the government dummy variables $S_{\mathrm{G}}$ and $R_{\mathrm{G}}\left(L_{\mathrm{G}}\right.$ is the reference dummy) suggest that right-wing governments choose a significantl higher summary earnings relationship than left or stalemate governments (columns 1-3). Our results imply that a change in government (in a fictitiou country) from the French Socialist François Mitterrand to the American Republican George W. Bush leads to an increase of roughly $10 \%$ in the earnings relationship. The same qualitative result will be obtained if we estimate the parameters of our second specification including the continuous variable $\mathrm{RW}_{\mathrm{G}}$ (columns 4-6). Hence, there is supportive evidence for Prediction 2.

According to Prediction 3, global goods market integration affects the earnings relationship of benefits The estimated parameters for our proxy for global goods market integration (Openness) are always significantl negative. A standard deviation increase in openness (31.574) goes along with a $25 \%$ decrease in the overall earnings relationship.

All of the theoretical predictions are conditional on a given level of UI benefits Our parameter estimates for the summary replacement rate RR are consistently positive and highly significant Hence, a more generous level of UI compensation goes hand-in-hand with a higher earnings relationship. Moreover, note that the parameter estimates for the lagged unemployment rate are never significantl different from zero in the specification for the summary earnings relationship $c_{-}$all of UI benefits Thus, we f nd no evidence that the level of unemployment has an impact on the earnings relationship of UI benefits ${ }^{13}$

\footnotetext{
${ }^{13}$ Note that Saint-Paul (1996) observes no effect of the (lagged) unemployment rate on the level of benefits whereas Di Tella and MacCulloch (2002) obtain some negative estimates.
} 


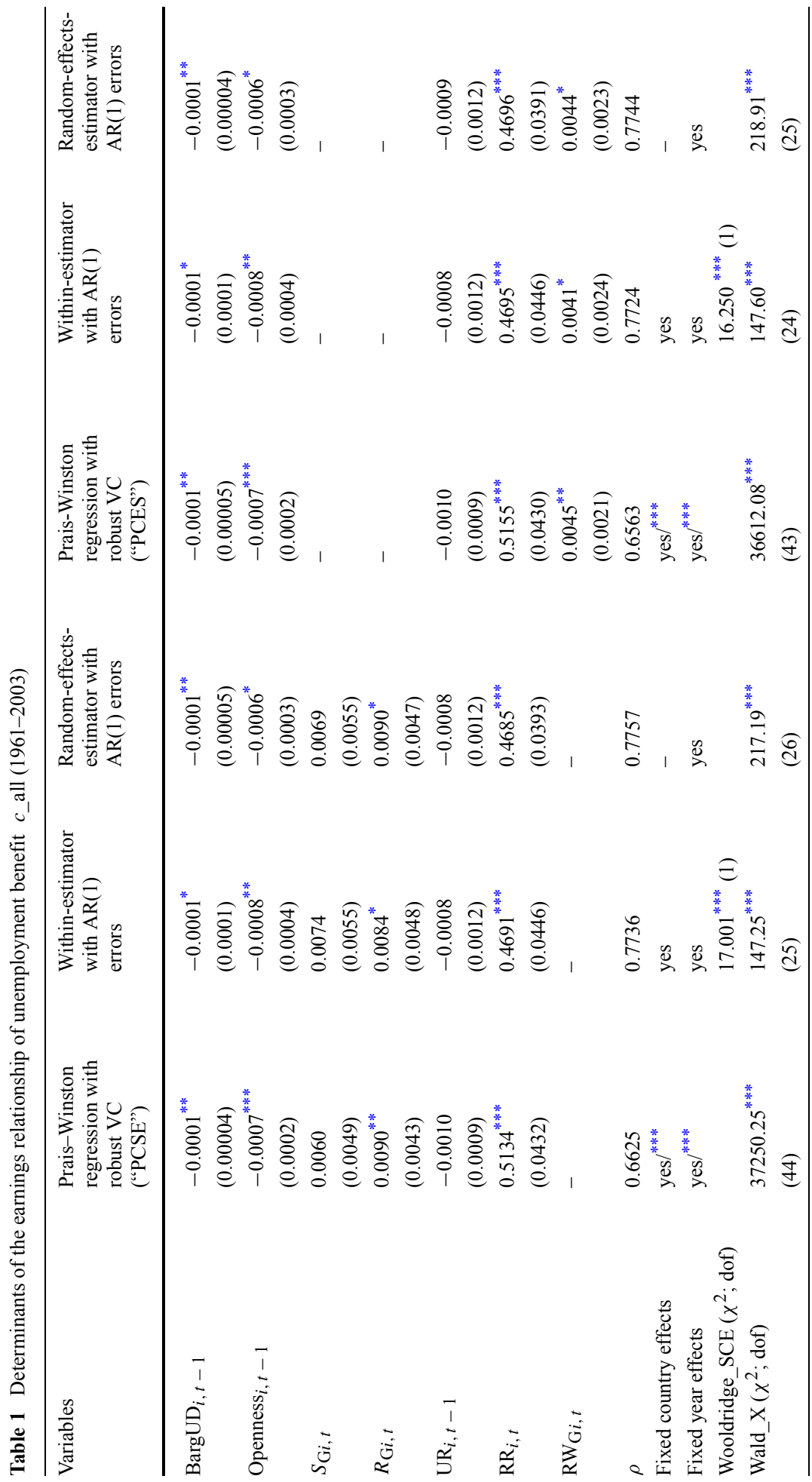




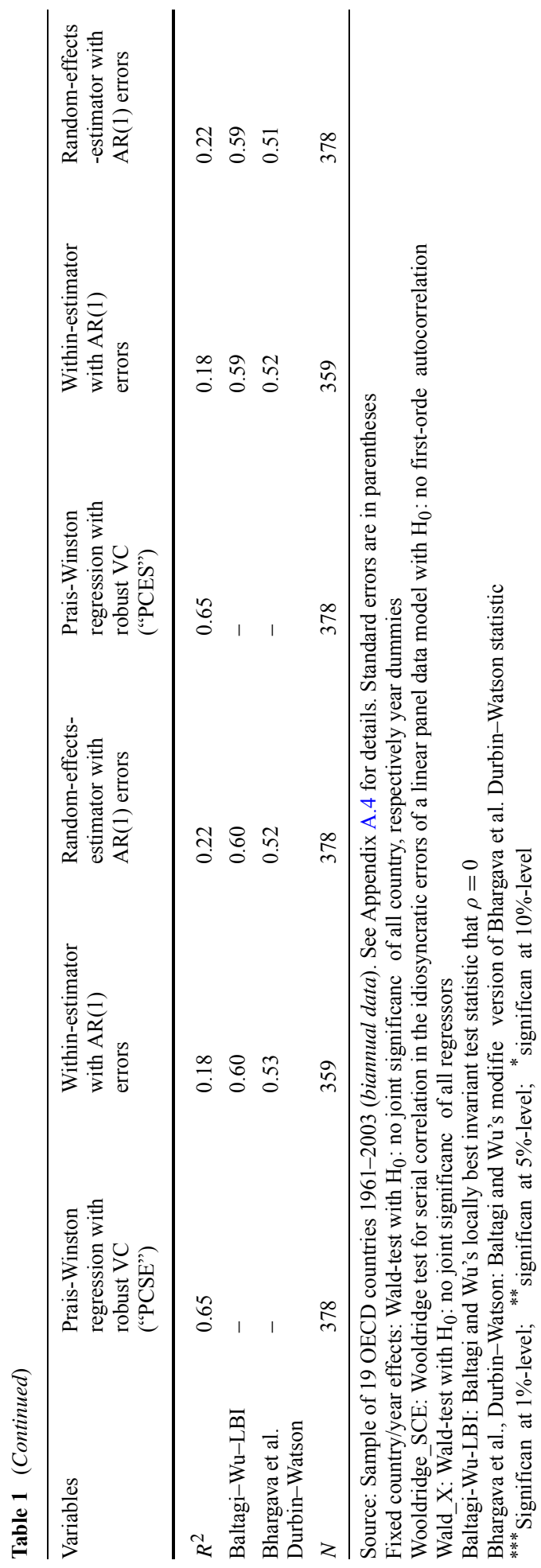


Our summary measure of the earnings relationship is based on data including unemployment insurance payments, unemployment assistance, and other transfers. The sensitivity of, for example, social assistance payments and housing benefit to previous earnings is likely to be determined differently than the earnings relationship of UI benefits This might lead to measures of $c$ which do not accurately describe the earnings relationship of the UI system that is portrayed in our theoretical model. We therefore also use measures of $\mathrm{c}$ for different unemployment durations to check for the robustness of our results. Table 2 shows the parameter estimates of the Prais-Winston regressions with a robust variance matrix ("PCSE") for both specification of (5.2): ${ }^{14}$

With respect to unemployment durations of up to 6 months, which are generally covered by UI systems, the only significan parameter estimate is that for the level of the replacement rate. Considering very long unemployment durations of 4 to 5 years, we additionally fin evidence that the political power of trade unions and the measure $c_{-} 45$ are negatively correlated. Moreover, for the two indicators of the earnings relationship c ( $c_{-} 712$ and c_23), which result from unemployment insurance, unemployment assistance and welfare payments, and hence vary substantially across OECD countries, we observe parameter estimates similar to the ones obtained for the summary measure of the earnings relationship $c$. In particular, we f nd that trade union power, as well as (a lagged measure of) openness and the respective $c \_d$ values, are negatively correlated, and that right-wing governments tend to prefer higher earnings relationships of UI benefits $-\mathrm{g}$ ven the level of the replacement rate.

We briefl discussed in Sect. 5 above whether the disincentive effects of unemployment compensation are determined by the net instead of the gross replacement ratio. To account for this possibility, we use OECD data on net replacement rates NRR for the initial phase of unemployment, which is available annually for the years 2001-2006, to calculate a summary measure of the net earnings relationship of UI benefit (labeled $c$ net). ${ }^{15}$

A f rst idea of the consequences of using the net instead of the gross measures can be obtained by comparing their absolute values. The correlation between the net replacement rates NRR for all 19 countries and our measures RR_012 of gross replacement rates for the firs year of unemployment and the years 2001 and 2003 is $0.82 .{ }^{16}$ The correlation between the measure of the earnings relationship of net benefit $c \_$net and our measure $c \_012$ for the firs year of unemployment based on gross replacement rates is 0.73 . This suggests that the gross replacement rates and the earnings relationships derived from them are closely linked to variables focusing on net payments. Accordingly, one may conjecture that the finding presented above based on gross payments are unlikely to be altered if net variables are used.

To corroborate this conjecture, we re-estimate the model described by (5.2) for the years 2001 to 2006, using $c \_$net and NRR instead of the measures $c$ and RR based on gross replacement rates. The resulting panel data set confronts us with the problem that most of the variables (covariates) rarely change over the six-year period under consideration. It is

\footnotetext{
${ }^{14}$ Results for the two other specification are in line with those presented in Table 2 and available upon request.

${ }^{15}$ The data on the net replacement rates for two earnings levels $(67 \%$ and $100 \%$ of an average worker's income) is employed to calculate $c$ _net in accordance with the procedure summarized by (5.1). The data set is described in Appendix A.4. Figure 6 in Appendix A.4 shows plots of $c_{-}$net for all 19 countries.

${ }^{16}$ This is consistent with Martin's evaluation (1996, p. 107) for the mid-nineties that the "country rankings of gross and net replacement rates are strongly correlated". Neugart (2005), using —in our terminology — the measures NRR for the two income levels and RR_all for 1999, find correlations between 0.54 and 0.66 . See also the discussion in Howell and Rehm (2009).
} 
Table 2 Determinants of short- and long-run earnings relationships of unemployment benefit (1961-2003). Prais-Winston regression with robust VC ("PCSE")

\begin{tabular}{|c|c|c|c|c|}
\hline Variables & $\begin{array}{l}\text { Unemployment } \\
\text { duration: } \\
\text { up to } 6 \text { months } \\
\text { c_06 }\end{array}$ & $\begin{array}{l}\text { Unemployment } \\
\text { duration: } \\
\text { 7-12 months } \\
\text { c_712 }\end{array}$ & $\begin{array}{l}\text { Unemployment } \\
\text { duration: } \\
2-3 \text { years } \\
\text { c_23 }\end{array}$ & $\begin{array}{l}\text { Unemployment } \\
\text { duration: } \\
4-5 \text { years } \\
\text { c_45 }\end{array}$ \\
\hline $\operatorname{BargUD}_{i, t-1}$ & $\begin{array}{l}0.0001 \\
(0.0001)\end{array}$ & $\begin{array}{l}-0.0002^{*} \\
(0.0001)\end{array}$ & $\begin{array}{l}-0.0001^{* * *} \\
(0.0001)\end{array}$ & $\begin{array}{l}-0.00004^{*} \\
(0.00002)\end{array}$ \\
\hline Openness $_{i, t}-1$ & $\begin{array}{l}-0.0007 \\
(0.0005)\end{array}$ & $\begin{array}{l}-0.0008^{* *} \\
(0.0004)\end{array}$ & $\begin{array}{l}-0.0009^{* * *} \\
(0.0002)\end{array}$ & $\begin{array}{l}-0.00004 \\
(0.0001)\end{array}$ \\
\hline$S_{\mathrm{G} i, t}$ & $\begin{array}{l}0.0120 \\
(0.0127)\end{array}$ & $\begin{array}{l}0.0184 \\
(0.0114)\end{array}$ & $\begin{array}{l}0.0100^{*} \\
(0.0058)\end{array}$ & $\begin{array}{l}-0.0035 \\
(0.0039)\end{array}$ \\
\hline$R_{\mathrm{G} i, t}$ & $\begin{array}{l}0.0112 \\
(0.0118)\end{array}$ & $\begin{array}{l}0.0197^{*} \\
(0.0102)\end{array}$ & $\begin{array}{l}0.0109^{* *} \\
(0.0052)\end{array}$ & $\begin{array}{l}0.0009 \\
(0.0037)\end{array}$ \\
\hline $\mathrm{UR}_{i, t-1}$ & $\begin{array}{l}-0.0044 \\
(0.0028)\end{array}$ & $\begin{array}{l}-0.0050^{* *} \\
(0.0022)\end{array}$ & $\begin{array}{l}-0.0002 \\
(0.0012)\end{array}$ & $\begin{array}{l}-0.0011^{*} \\
(0.0006)\end{array}$ \\
\hline $\mathrm{RR}_{i, t \_\mathrm{d}}$ & $\begin{array}{l}1.1383^{* * *} \\
(0.0692)\end{array}$ & $\begin{array}{l}0.7862^{* * *} \\
(0.0437)\end{array}$ & $\begin{array}{l}0.6158^{* * *} \\
(0.0382)\end{array}$ & $\begin{array}{l}0.1082^{* * *} \\
(0.0245)\end{array}$ \\
\hline$\rho$ & 0.5467 & 0.5540 & 0.6484 & 0.6666 \\
\hline $\mathrm{RW}_{\mathrm{G} i, t}$ & $\begin{array}{l}0.0048 \\
(0.0058)\end{array}$ & $\begin{array}{l}0.0103^{* *} \\
(0.0047)\end{array}$ & $\begin{array}{l}0.0052^{* *} \\
(0.0026)\end{array}$ & $\begin{array}{l}0.0008 \\
(0.0018)\end{array}$ \\
\hline Fixed country effects & yes $^{* * *}$ & yes ${ }^{* * *}$ & yes ${ }^{* * *}$ & yes ${ }^{* * *}$ \\
\hline Fixed year effects & yes $^{* * *}$ & yes $/^{* * *}$ & yes $/^{* * *}$ & yes $/^{* * *}$ \\
\hline Wooldridge_SCE $\left(\chi^{2} ;\right.$ dof $)$ & $15.928^{* * *}(1)$ & $5.672^{* *}(1)$ & $20.527^{* * *}(1)$ & $130.124^{* * *}(1)$ \\
\hline$R^{2}$ & 0.76 & 0.81 & 0.75 & 0.53 \\
\hline $\begin{array}{l}\text { Wald_X } \\
\left(\chi^{2} ; \text { dof }\right)\end{array}$ & $\begin{array}{l}9.57 \mathrm{e}+07^{* * *} \\
(44)\end{array}$ & $\begin{array}{l}228697.4^{* * *} \\
(44)\end{array}$ & $\begin{array}{l}298033.33^{* * *} \\
(44)\end{array}$ & $\begin{array}{l}137309.01^{* * *} \\
(44)\end{array}$ \\
\hline$N$ & 378 & 378 & 378 & 378 \\
\hline
\end{tabular}

Source: Sample of 19 OECD countries 1961-2003 (biannual data). See Appendix A.4 for details Standard errors are in parentheses

Fixed country/year effects: Wald-test with $\mathrm{H}_{0}$ : no joint significanc of all country, respectively year dummies As in Table 1 there are two specification for each unemployment duration: Specificatio I includes $S_{\mathrm{G} i, t}$ and $R_{\mathrm{Gi} i t}$ and is documented in its entirety in Table 2. Specificatio II incorporates $\mathrm{RW}_{\mathrm{G}}$. Only the estimated coefficient for $\mathrm{RW}_{\mathrm{G}}$ are documented. Test statistics are provided for specificatio I

Wooldridge_SCE: Wooldridge test for serial correlation in the idiosyncratic errors of a linear panel data model with $\mathrm{H}_{0}$ : no first-orde autocorrelation

Wald_X: Wald-test with $\mathrm{H}_{0}$ : no joint significanc of all regressors

${ }^{* * *}$ Signif cant at $1 \%$-level; ${ }^{* *}$ signif cant at $5 \%$-level; ${ }^{*}$ significan at $10 \%$-level

well known (see, e.g., Beck 2007) that applying standard econometric specification with country-fi ed effects gives rise to estimates indicating that slowly changing variables, such as political or wage bargaining institutions, have no impact. This general experience also holds for our data. However, to test whether there are significan correlations between $c$ _net and our covariates based on the cross-sectional variation of the covariates in our data set (between variation), we use the following three econometric procedures: (1) pooled OLS with fi ed-time effects and "panel corrected standard errors"; (2) fi ed effects vector decomposition with fi ed-country effects, fi ed-year effects, and "panel corrected standard errors", a procedure specificall designed for data sets such as ours (Plümper and Troeger 2007); and 
(3) a random effects estimator with random country effects, fi ed-year effects, and standard errors which are robust to general second moment misspecification ${ }^{17}$

With respect to the variable BargUD, the interaction of union density and the bargaining level, we fin significantl negative correlations across all specifications which are in line with our previous results and again provide supportive evidence for Prediction 1. Moreover, considering the estimates for our political variables, the econometric procedures (1) and (2) corroborate our conclusion that left-wing governments select a weaker earnings relationship of UI benefit (Prediction 2). Finally, the estimated parameters of openness are significantl negative in the specification based on procedure (1). We thus cannot fin any indication that our main empirical finding are particularly sensitive to the use of gross instead of net replacement rates.

\section{Summary}

In this paper, we model endogenous labor market regulation using the political support function approach which is based on the presumption that well-organized interests directly affected by a given policy measure will, in the fina analysis, determine the political outcome. Assuming a unionized labor market, we show that the political influenc of trade unions can reduce the earnings relationship of unemployment compensation. The reason for this is that a strong earnings relationship reduces wages (if the fraction of utilitarian unions is not too high). Lower wages, however, reduce union utility and thereby the union's political support for the government. Moreover, we show that left-wing governments prefer a weaker earnings relationship of UI payments than centre or right-wing governments, and that globalization exerts a distinct influenc on the earnings relationship. To test these predictions, we created a new data set based on information on gross replacement rates for 19 OECD countries covering the period 1961-2003. The panel analysis provides evidence in support of our predictions, and consequently gives credence to the firs positive theory of the earnings relationship of UI benefits The finding for a more recent but much shorter sample using information on net replacement rates corroborate our results for the gross rates.

Acknowledgements We are grateful to seminar participants at various universities for their constructive comments and especially to two anonymous referees for their extremely helpful suggestions.

\section{Appendix A}

\section{A.1 Second-order condition}

The second-order condition implies $\partial K^{s} / \partial w^{s}<0$. Assuming a constant labor demand elasticity and omitting the superscript $s$ on the right-hand side of (A.1), $\partial K^{s} / \partial w^{s}$ equals:

$$
\begin{aligned}
\frac{\partial K^{\mathrm{s}}}{\partial w^{\mathrm{s}}}= & \left\{(\varepsilon+1)\left(v^{\prime}-\bar{v}^{\prime} c\right)+w\left(v^{\prime \prime}-\bar{v}^{\prime \prime} c^{2}\right)+\frac{\lambda M}{n}\left(\bar{v}^{\prime} c(1-\varepsilon)+w \bar{v}^{\prime \prime} c^{2}\right)\right\} \pi \\
& -\underbrace{(n(v-\bar{v})+\lambda M \bar{v})}_{+}-2 n w \underbrace{\left[\frac{\varepsilon}{w}(v-\bar{v})+v^{\prime}-\bar{v}^{\prime} c+\frac{\lambda M}{n} \bar{v}^{\prime} c\right]}_{\text {positive from FOC }}<0 .
\end{aligned}
$$

\footnotetext{
${ }^{17}$ A table with all estimated parameters is available from the authors on request. All covariates are generated along the lines described in Appendix A.4. Current information on union density stems from Visser (2009).
} 
The second-order condition will unambiguously hold if the term in the curly brackets in (A.1) is negative. If $K^{\mathrm{s}}$ is differentiated with respect to the wage $w^{\mathrm{s}}$ for a given level of UI benefit $B^{\mathrm{s}}$, the wage change alters neither $\bar{v}\left(B^{\mathrm{s}}\right)$ nor $\bar{v}^{\prime}\left(B^{\mathrm{s}}\right)$. This differential, $\bar{K}_{w}:=\left.\frac{\partial K^{\mathrm{s}}}{\partial w^{\mathrm{s}}}\right|_{\mathrm{d} B^{\mathrm{s}}=0}$, is clearly negative for $\left(1-\frac{\lambda M}{n}\right) \geq 0$, given the second-order condition:

$$
\begin{aligned}
\bar{K}_{w}:= & {\left[(\varepsilon+1) v^{\prime}-\bar{v}^{\prime} c+w v^{\prime \prime}+\frac{\lambda M}{n} \bar{v}^{\prime}(1-\varepsilon) c\right] \pi } \\
& -n\left[\varepsilon(v-\bar{v})+w\left(v^{\prime}-\bar{v}^{\prime} c\right)\right]-\lambda M \bar{v}^{\prime} c w \\
& -\left[n(v-\bar{v})+\lambda M \bar{v}+w\left(n_{w}(v-\bar{v})+n v^{\prime}\right)\right] \\
= & \frac{\partial K^{\mathrm{s}}}{\partial w^{\mathrm{s}}}+\underbrace{\pi \varepsilon \bar{v}^{\prime} c}_{-}+\underbrace{\left(1-\frac{\lambda M}{n}\right) c w \underbrace{\left[\bar{v}^{\prime \prime} c \pi-n \bar{v}^{\prime}\right]}_{-} .}_{- \text {if } \mathrm{C} \text { holds }} .
\end{aligned}
$$

\section{A.2 The open economy case (Prediction 3)}

Assume that international integration reduces the prices of tradable goods. To capture this effect, let $\phi, 0<\phi \leq 1$, be a measure of the economy's openness and suppose, furthermore, that the price $p^{\mathrm{e}}$ is a function of output, as long as the market for tradable goods is not perfectly competitive. The price $p^{\mathrm{e}}$ can then, for example, be written as

$$
p^{\mathrm{e}}=\Theta(\phi)\left(f^{\mathrm{e}}\right)^{\phi-1}
$$

where $\partial p^{\mathrm{e}} / \partial \phi<0$ holds by assumption. For $\phi=1$, the output price equals the constant world market price: $\Theta(1)=1$. Thus, an increase in $\phi$, starting from a positive value below unity, indicates stronger international competition. Suppose, in addition, that the production function in the exposed sector is given by $f^{\mathrm{e}}=\left(n^{\mathrm{e}}\right)^{\delta}, 0<\delta<1$. Profit can then be expressed as

$$
\pi^{\mathrm{e}}=\Theta(\phi)\left(n^{\mathrm{e}}\right)^{\delta \phi}-w^{\mathrm{e}} n^{\mathrm{e}}
$$

Maximizing profit with respect to employment and solving for $n^{\mathrm{e}}$ yields:

$$
n^{\mathrm{e}}=\left(\frac{w^{\mathrm{e}}}{\Theta \delta \phi}\right)^{1 /(\delta \phi-1)} .
$$

The labor demand elasticity equals $\varepsilon^{\mathrm{e}}=1 /(\delta \phi-1)<-1$. Moreover, $\varepsilon_{\phi}^{\mathrm{e}}=-\delta /(\delta \phi-1)^{2}$ $<0$ holds. The direction of the employment change (for a given wage) is ambiguous:

$$
n_{\phi}^{\mathrm{e}}=\frac{\partial \ln \left(n^{\mathrm{e}}\right)}{\partial \phi} n^{\mathrm{e}}=n^{\mathrm{e}}\left[\frac{-\delta}{(\delta \phi-1)^{2}} \ln \left(\frac{w^{\mathrm{e}}}{\Theta \delta \phi}\right)-\frac{\Theta_{\phi} \phi-\Theta}{(\delta \phi-1) \Theta \phi}\right]=\frac{n^{\mathrm{e}}}{1-\delta \phi}\left[\frac{\partial p^{\mathrm{e}}}{\partial \phi} \frac{1}{p^{\mathrm{e}}}+\frac{1}{\phi}\right] \text {. }
$$

Holding the wage constant, profit $\pi^{\mathrm{e}}=w^{\mathrm{e}} n^{\mathrm{e}}(1 /(\delta \phi)-1)$ decline with $\phi$ :

$$
\frac{\partial \pi^{\mathrm{e}}}{\partial \phi}=w^{\mathrm{e}}\left[n_{\phi}^{\mathrm{e}}\left(\frac{1-\delta \phi}{\delta \phi}\right)-\frac{n^{\mathrm{e}}}{\delta \phi^{2}}\right]=w^{\mathrm{e}} n^{\mathrm{e}} \frac{p_{\phi}^{\mathrm{e}}}{\phi \delta p^{\mathrm{e}}}<0
$$


The wage in the exposed sector is (implicitly) define by (2.4). Assume now that $v$ is homogeneous in the consumer price, ${ }^{18}$ and goods are consumed in fi ed proportions, so that the consumer price index can be normalized to $p=p^{\mathrm{s}}+p^{\mathrm{e}}$. Cancelling common terms, substituting for $n^{\mathrm{e}}$, and using $v^{\mathrm{e}}:=v^{\mathrm{e}}\left(w^{\mathrm{s}} / p\right)$ and $\bar{v}^{\mathrm{e}}:=v^{\mathrm{e}}\left(B^{\mathrm{s}} / p\right)$, the bargaining outcome is given by

$$
K^{\mathrm{e}}=\varepsilon^{\mathrm{e}}+w^{\mathrm{e}} \frac{v^{\mathrm{e} \prime}-\bar{v}^{\mathrm{e} \prime}\left(1-\frac{\lambda^{\mathrm{e}} M^{\mathrm{e}}}{n^{\mathrm{e}}}\right) c}{v^{\mathrm{e}}-\bar{v}^{\mathrm{e}}}-\left(\frac{\delta \phi}{1-\delta \phi}+\frac{w^{\mathrm{e}} \lambda^{\mathrm{e}} M^{\mathrm{e}} \bar{v}^{\mathrm{e}}}{\left(v^{\mathrm{e}}-\bar{v}^{\mathrm{e}}\right) \pi^{\mathrm{e}}}\right)=0 .
$$

For a given level of benefits a rise in the parameter $\phi$ will unambiguously decrease the wage in the exposed sector if employment weakly increases in $\phi$, that is, if $n_{\phi}^{\mathrm{e}} \geq 0$ :

$$
w_{\phi}^{\mathrm{e}}:=\left.\frac{\partial w^{\mathrm{e}}}{\partial \phi}\right|_{\mathrm{d} B^{\mathrm{e}}=0}=-\{\underbrace{\varepsilon_{\phi}^{\mathrm{e}}}_{(-)}+\underbrace{\frac{w^{\mathrm{e}} \lambda^{\mathrm{e}} M^{\mathrm{e}}}{v^{\mathrm{e}}-\bar{v}^{\mathrm{e}}}}_{(+)} \underbrace{\frac{\bar{v}^{\mathrm{e}} \pi_{\phi}^{\mathrm{e}}}{\left(\pi^{\mathrm{e}}\right)^{2}}}_{(-)}-\underbrace{\left.\frac{c \bar{v}^{\prime \mathrm{e}}}{\left(n^{\mathrm{e}}\right)^{2}} n_{\phi}^{\mathrm{e}}\right]}_{(-) \text {if } n_{\phi}^{\mathrm{e}}>0}-\underbrace{\frac{\delta}{(1-\delta \phi)^{2}}}_{+}\} / \frac{\partial \bar{K}^{\mathrm{e}}}{\partial w^{\mathrm{e}}}
$$

where $\partial \bar{K}^{\mathrm{e}} / \partial w^{\mathrm{e}}<0$ is def ned by $\partial K^{\mathrm{e}} / \partial w^{\mathrm{e}}$ evaluated at $\mathrm{d} B^{\mathrm{e}}=0$. The wage effect appears since an increase in $\phi$ reduces the rent to be shared. Moreover, the labor demand elasticity $\left(\varepsilon^{\mathrm{e}}<0\right)$ increases in absolute value. Profit in the exposed sector fall and the Nash-bargaining solution requires a decline in wages. Because employment increases with globalization, a stronger earnings relationship reduces the union's payoff by less than before the increase in competition, also inducing a wage reduction. In the sheltered sector, the wage is unaffected, due to the f rm's revenues remaining constant and because of the assumption of a homogeneous utility function.

Taking into account the wage effects summarized above, the consequences of an increase in $\phi$ for the government's optimal choice of the earnings relationship $c^{*}$ are determined via:

$$
\left.\frac{\partial S_{c}}{\partial \phi}\right|_{\mathrm{d} B^{\mathrm{e}}=\mathrm{d} B^{\mathrm{s}}=0}=\alpha \beta_{\mathrm{U}} \underbrace{U_{c \phi}^{\mathrm{s}}}_{-}+\alpha \underbrace{U_{c \phi}^{\mathrm{e}}}_{+/-}+(1-\alpha) \beta_{F} \underbrace{\pi_{c \phi}^{\mathrm{s}}}_{=0}+(1-\alpha) \underbrace{\pi_{c \phi}^{\mathrm{e}}}_{(+)} .
$$

Assuming that Condition $\mathrm{C}$ holds and that the linkage between the earnings relationship of benefit and the wage is unaffected by a change in $\phi$, i.e., $\partial w_{c}^{j} / \partial \phi=0$, the impact of an increase in $\phi$ on the union's marginal utility $U_{c}^{\mathrm{s}}$ - for a given level of benefit $\left(\mathrm{d} B^{\mathrm{s}}=0\right)$-is negative:

$$
U_{c \phi}^{\mathrm{s}}:=\left.\frac{\partial U_{c}^{\mathrm{s}}}{\partial \phi}\right|_{\mathrm{d} B^{\mathrm{s}}=0}=-n^{\mathrm{s}} w_{c}^{\mathrm{s}} \frac{\varepsilon^{\mathrm{s}}(v-\bar{v})+w^{\mathrm{s}} v^{\prime}}{w^{\mathrm{s}} p^{2}} p_{\phi}^{\mathrm{e}}=-\frac{U_{c}^{\mathrm{s}} p_{\phi}^{\mathrm{e}}}{p}<0 .
$$

The overall change in the marginal utility of the union in the exposed sector is determined by

$$
U_{c \phi}^{\mathrm{e}}:=\left.\frac{\partial U_{c}^{\mathrm{e}}}{\partial \phi}\right|_{\mathrm{d} B^{\mathrm{e}}=0}=\underbrace{n_{\phi}^{\mathrm{e}} \frac{U_{c}^{\mathrm{e}}}{n^{\mathrm{e}}}}_{(-) \text {if } n_{\phi}^{\mathrm{e}}>0}+\underbrace{\varepsilon_{\phi}^{\mathrm{e}} w_{c}^{\mathrm{e}} n^{\mathrm{e}} \frac{v^{\mathrm{e}}-\bar{v}^{\mathrm{e}}}{w^{\mathrm{e}} p}}_{(+)}+\underbrace{\frac{\partial U_{c}^{\mathrm{e}}}{\partial w^{\mathrm{e}}} w_{\phi}^{\mathrm{e}}}_{(-) \text {for } w_{\phi}^{\mathrm{e}}<0}-\underbrace{\frac{U_{c}^{\mathrm{e}} p_{\phi}^{\mathrm{e}}}{p}}_{(+)} .
$$

\footnotetext{
${ }^{18}$ The assumption of homogeneity allows for a comparison of the price-induced changes in the utility levels $v^{\mathrm{e}}(w / p)$ and $v^{\mathrm{e}}(B / p)$. The subsequent finding will therefore also hold if either the utility function $v$ is homogeneous in the consumer price of degree $k, k>0$, or if $v$ is linear.
} 
The last term in (A.12) captures the effect that also appears in the sheltered sector. The third term and the wage effect will also contribute to an increase in the union's opposition to a stronger earnings relationship if globalization reduces wages $\left(w_{\phi}^{\mathrm{e}}<0, \mathrm{cf}\right.$. (A.9)). Finally, the direct employment impact will reduce the union's marginal gain from a stronger earnings relationship if $n_{\phi}^{\mathrm{e}}>0$ holds. But irrespective of the sign of $n_{\phi}^{\mathrm{e}}$, the overall impact of a change in $\phi$ on the union's marginal utility in the exposed sector is ambiguous. This ambiguity arises due to the second term, the elasticity effect, which is positive since $\varepsilon_{\phi}^{\mathrm{e}}<0, v^{\mathrm{e}}-\bar{v}^{\mathrm{e}}>0$ and $w_{c}^{\mathrm{e}}<0$, given Condition $\mathrm{C}$.

A firms payoff in the sheltered sector is unaffected by $\phi\left(\pi_{c \phi}^{\mathrm{s}}=0\right)$. The gain from a higher earnings relationship of UI benefit for $\mathrm{frms}$ in the exposed sector will unambiguously be positive if employment weakly rises with increasing competition $\left(n_{\phi}^{\mathrm{e}} \geq 0\right)$ :

$$
\pi_{c \phi}^{\mathrm{e}}:=\left.\frac{\partial \pi_{c}^{\mathrm{e}}}{\partial \phi}\right|_{\mathrm{d} B^{\mathrm{e}}=0}=-w_{c}^{\mathrm{e}}\left(n_{\phi}^{\mathrm{e}}+n_{w}^{\mathrm{e}} w_{\phi}^{\mathrm{e}}\right)>0, \quad \text { if } n_{\phi}^{\mathrm{e}} \geq 0 \text { and Condition } \mathrm{C} \text { holds }
$$

In sum, we fin that the costs of a stronger earnings relationship suffered by the union in the sheltered sector increase with $\phi$. The fir in the sheltered sector is unaffected. Moreover, the impact on the union in the exposed sector is ambiguous, while the gain of $\mathrm{f} \mathrm{rms} \mathrm{in}$ the exposed sector increases, given Condition C. Thus, a more competitive exposed sector reduces the earnings relation of UI benefit for a given level of unemployment compensation, as long as the political weight of trade unions in the sheltered sector is sufficientl high.

\section{A.3 Descriptive statistics}

Table 3 Raw correlation coefficient for different measures of the earnings relationship of benefit

\begin{tabular}{llllr}
\hline & $c_{-} 06$ & $c_{-} 712$ & $c_{-} 23$ & $c_{-} 45$ \\
\hline$c_{-} 06$ & 1.00 & & & \\
$c_{-} 712$ & 0.86 & 1.00 & & \\
$c_{-} 23$ & 0.61 & 0.69 & 1.00 & 1.00 \\
$c_{-} 45$ & 0.12 & 0.17 & 0.40 & \\
\hline
\end{tabular}

Sample of 19 OECD countries 1961-2003 (biannual data). $N=409$. See Appendix A.4 for details

Table 4 Descriptive statistics

\begin{tabular}{lcc}
\hline Variable & Mean & Std. dev. \\
\hline Measures of the earnings relationship & & \\
c_all & 0.089 & 0.101 \\
$c_{-} 06$ & 0.266 & 0.247 \\
$c_{-} 712$ & 0.206 & 0.237 \\
c_23 & 0.082 & 0.130 \\
c_45 & 0.023 & 0.063 \\
\hline
\end{tabular}


Table 4 (Continued)

\begin{tabular}{lrr}
\hline Variable & Mean & Std. dev. \\
\hline Replacement rates & & \\
RR & 0.221 & 0.140 \\
RR_06 & 0.468 & 0.189 \\
RR_712 $_{\text {R__23 }}$ & 0.362 & 0.243 \\
RR_45 & 0.210 & 0.187 \\
Other variables & 0.136 & 0.136 \\
Net Union Density & & \\
(UD) & 41.661 & 18.051 \\
Bargaining level & & \\
BargUD & 2.353 & 1.034 \\
Openness & 107.908 & 81.629 \\
Unemployment rate & 50.940 & 31.574 \\
(UR) & 5.432 & 4.017 \\
Stalemate Gov. $\left(S_{G}\right)$ & & \\
Right Gov. $\left(R_{G}\right)$ & 0.386 & 0.487 \\
Right-Wing Gov. & 0.362 & 0.481 \\
(RW & 2.059 & 0.771 \\
\hline
\end{tabular}

Sample of 19 OECD countries 1961-2003 (biannual data)

$N=409$ (for measures of earnings relationships $c$ and of gross replacement rates $\mathrm{RR}$ )

See Appendix A.4 for details on all variables and missing values

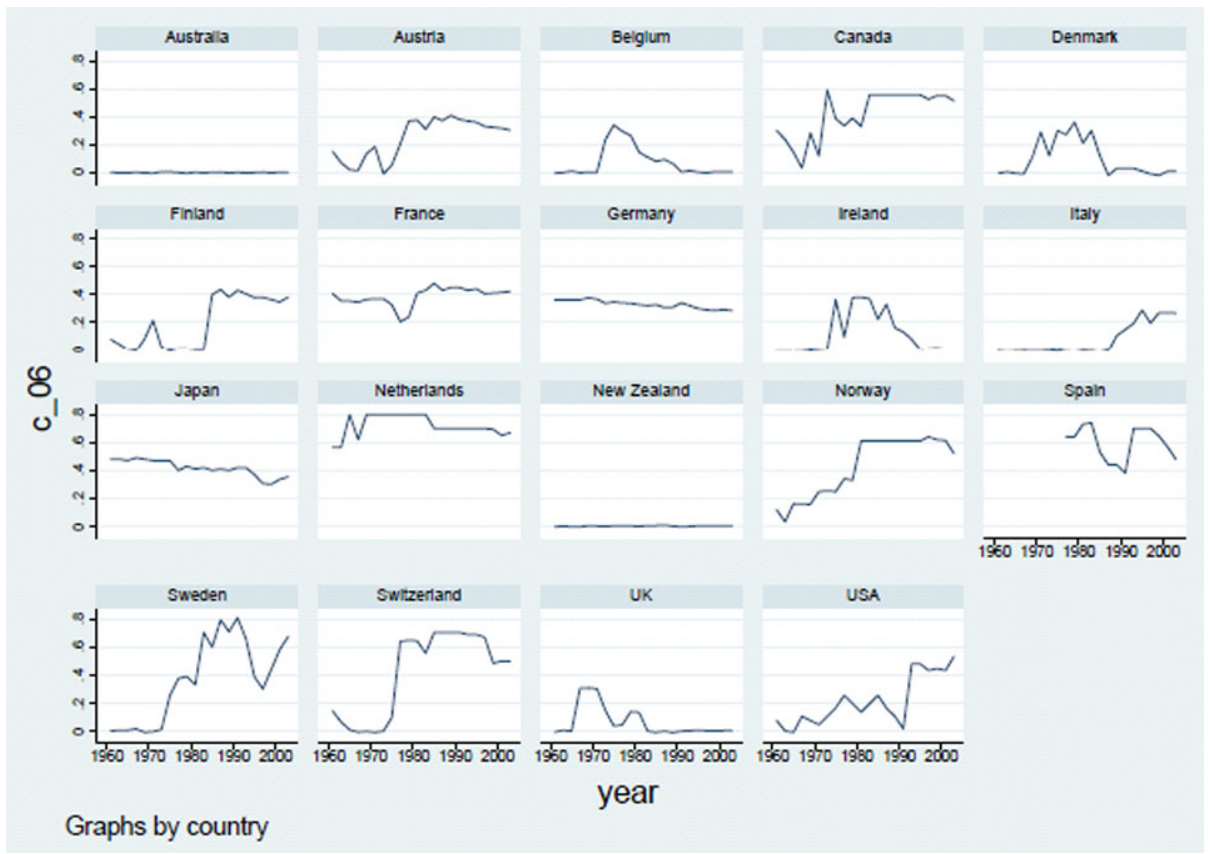

Fig. 2 Earnings relationship $c \_06$ for unemployment durations of 0-6 months (1961-2003).

Source: Own calculations based on OECD data. See Appendix A.4 


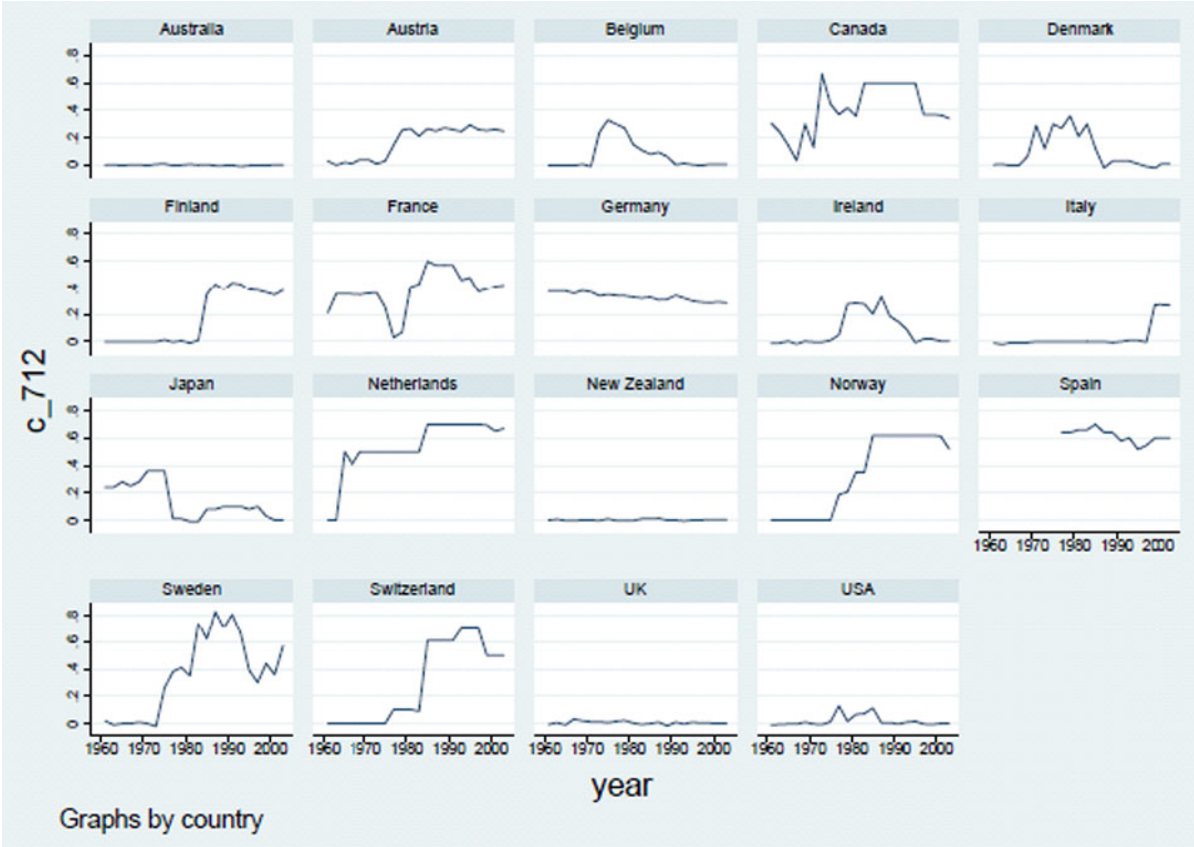

Fig. 3 Earnings relationship $c_{-} 712$ for unemployment durations of 7-12 months (1961-2003).

Source: Own calculations based on OECD data. See Appendix A.4

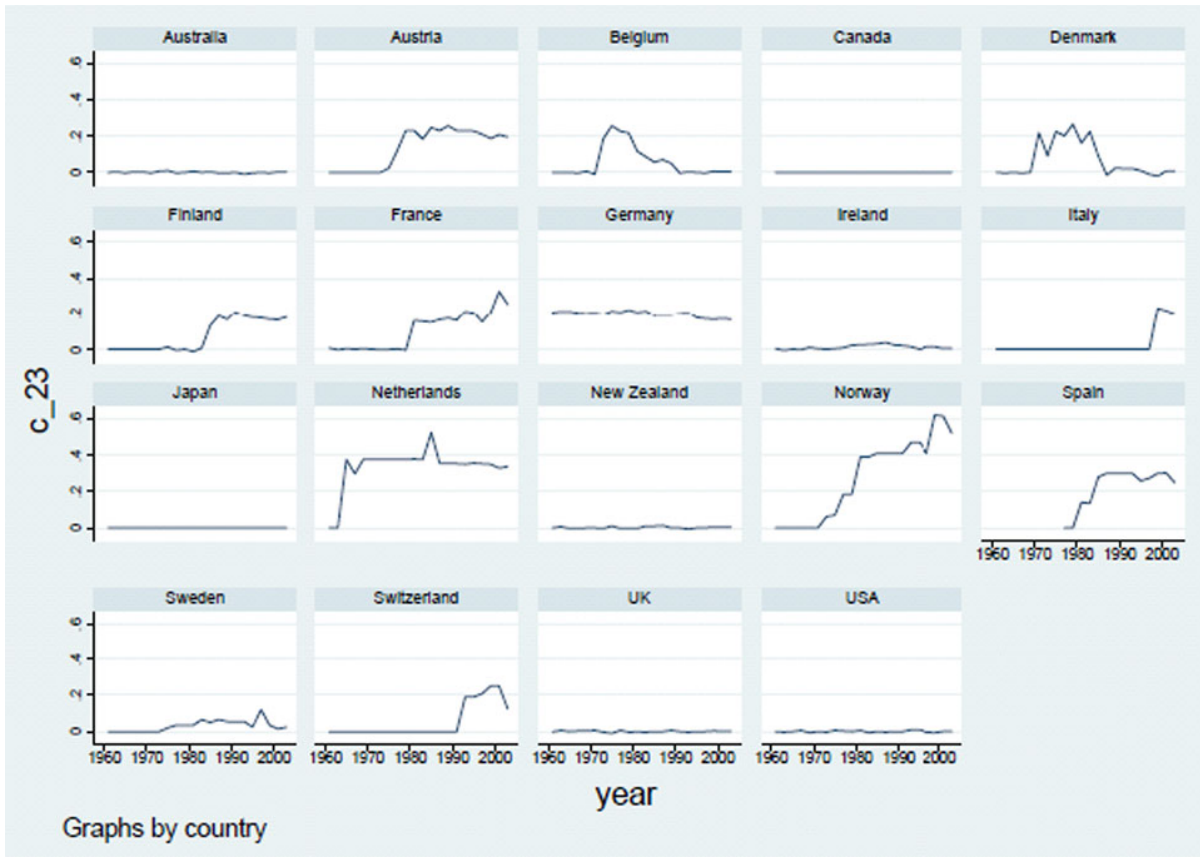

Fig. 4 Earnings relationship $c \_23$ for unemployment durations of 2-3 years (1961-2003).

Source: Own calculations based on OECD data. See Appendix A.4 


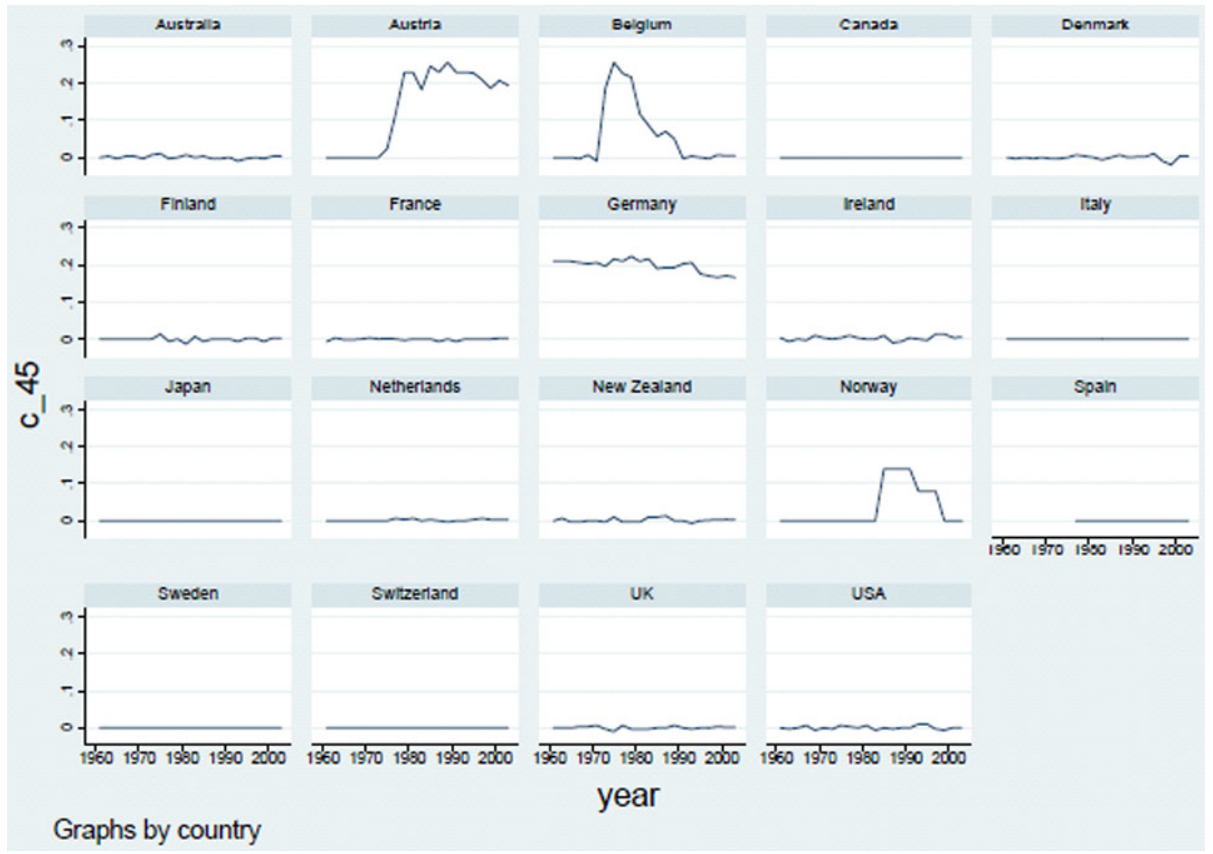

Fig. 5 Earnings relationship $c \_45$ for unemployment durations of 4-5 years (1961-2003). Source: Own calculations based on OECD data. See Appendix A.4

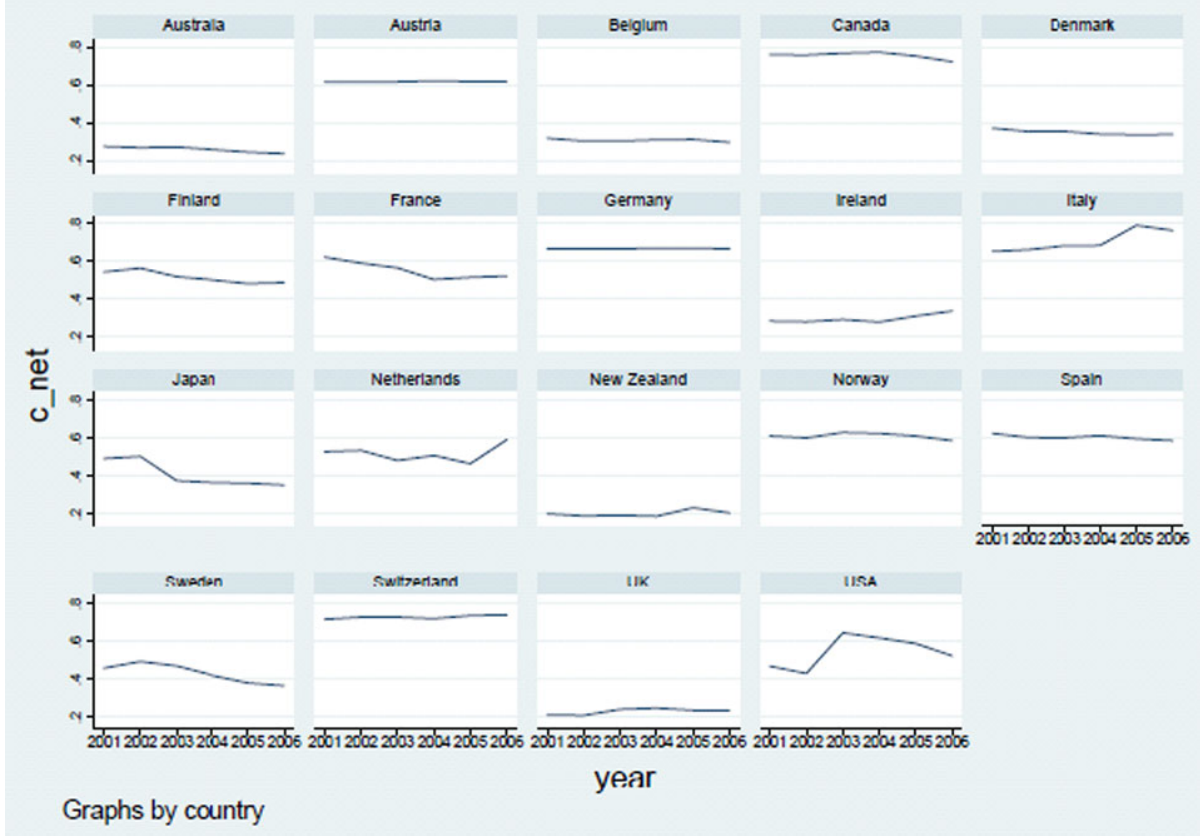

Fig. 6 Earnings relationship $c$ net based on net replacement rates (2001-2006).

Source: Own calculations based on OECD data. See Appendix A.4 


\section{A.4 Data}

Information on the earnings relationship of unemployment benefit $\left(c \_d\right)$ is calculated using the OECD's Database on Benefi Entitlements and Gross Replacement Rates for the years 1961-2003 as described in Sect. 5. These measures are used in the main part of the paper. Countries included in our sample are Australia, Austria, Belgium, Canada, Denmark, Finland, France, Germany, Ireland, Italy, Japan, Netherlands, New Zealand, Norway, Spain, Sweden, Switzerland, UK, and the US. Information for Spain is only used from 1977 onward. Information on the earnings relationship $c$ is missing for New Zealand for the year 1997.

The unemployment rate (UR) is the standardized unemployment rate from the "Labour Market Institutions Database (LMIDB)" collected by Nickell and Nunziata (2001) and is updated using information from OECD's Employment Outlook and from Armingeon et al. (2008).

The data on net union density originate from Nickell and Nunziata's (2001) LMIDB, which is updated using information from a fil generously provided by Hagen Lesch (IW Köln) and from Visser's (2009) ICTWSS Database.

The information on the bargaining level at which wages are determined is taken from Golden and Wallerstein (2004) ["barglev1"] and has been updated by our own calculations using additional information from Armingeon et al. (2008) and Du Caju et al. (2008). It is coded as follows: $1=$ plant-level wage setting; $2=$ industry-level wage setting; $3=$ central wage setting without sanctions; $4=$ central wage setting with sanctions. Sanctions refer to legally enforceable sanctions against industrial conflic or situations in which lower level trade union branches do not have access to strike funds without prior authorization from higher-ranking authorities within the trade union (movement) (Golden and Wallerstein 2004, p. 31).

Openness is the sum of exports and imports of goods and services as a percentage of GDP. It is calculated using information provided by the OECD and the World Bank's World Development Indicators (WDI). For Denmark (3), France (1), Germany (4), New Zealand (2), and Switzerland (2), there are missing values.

The dummies "left" governments $\left(L_{\mathrm{G}}\right)$ (consisting of social democratic parties and parties to their left), "right" governments $\left(R_{\mathrm{G}}\right)$ (consisting of liberal or conservative parties), and "stalemate" governments $\left(S_{\mathrm{G}}\right)$ (coalitions of parties) are based on a government composition index (govcomp) generously provided by Thomas Cusack (WZB). This is an extended version of an index initially suggested by Rothschild (1986) and has been updated by our own calculations using additional information from Armingeon et al. (2008).

The variable right-wing government $\left(\mathrm{RW}_{\mathrm{G}}\right)$ is taken from two sources. First, we make use of information on cabinet composition as given by the percentage of total cabinet posts weighted by days in offic for "social democratic/other left" parties, "centre" parties, and "right-wing" parties. This index is provided by Armingeon et al. (2008). Second, we employ Cusack's government composition index described above. Our variable right-wing government $\left(\mathrm{RW}_{\mathrm{G}}\right)$ is the product of the two indices, i.e., the percentages of total cabinet posts are weighted by a "left-right scale" of government composition and aggregated across all cabinet parties.

As a robustness check, we generate a summary measure of the earnings relationship of unemployment benefit ( $c$ _net) based on OECD data on net replacement rates for the initial phase of unemployment for the years 2001-2006, according to the approach described in the main part of our paper. The data is available at http://www.oecd.org/dataoecd/17/21/ 39720238.xls. Countries included in our sample are the ones listed above. The calculations 
of all covariates used in these supplementary regressions and their data sources are also as described above.

\section{References}

Agell, J. (2002). On the determinants of labour market institutions: rent-seeking vs. social insurance. German Economic Review, 2(2), 107-135.

Anesi, V., \& De Donder, P. (2009). A positive theory of unemployment insurance and employment protection. CEPR discussion paper No. 7333.

Armingeon, K., Gerber, M., Leimgruber, P., \& Beyeler, M. (2008). Comparative political data set 19602006. Institute of Political Science, University of Bern.

Atkinson, A. B. (1990). Income maintenance for the unemployed in Britain and the response to high unemployment. Ethics, 100(3), 569-585.

Atkinson, A. B., \& Micklewright, J. (1989). Turning the screw: benefit for the unemployed 1979-88. In A. Dilnot \& I. Walker (Eds.), The economics of social security (pp. 17-51). Oxford: Oxford University Press.

Baltagi, B. H. (2005). Econometric analysis of panel data. New York: Wiley.

Beck, N. (2007). From statistical nuisances to serious modeling: changing how we think about the analysis of time-series-cross-section data. Political Analysis, 15(2), 97-100.

Beissinger, T., \& Egger, H. (2004). Dynamic wage bargaining if benefit are tied to individual wages. Oxford Economic Papers, 56(3), 437-460.

Blanchard, O., \& Tirole, J. (2008). The joint design of unemployment insurance and employment protection: a firs pass. Journal of the European Economic Association, 6(1), 45-77.

Boeri, T., Conde-Ruiz, J., \& Galasso, V. (2003). Protecting against labour market risk: employment protection or unemployment benefits. IZA discussion paper No. 834.

Boeri, T., Conde-Ruiz, J., \& Galasso, V. (2004). Cross-skill redistribution and the trade-off between unemployment benefits and employment protection. IZA discussion paper No. 1371.

Boeri, T., Conde-Ruiz, J., \& Galasso, V. (2006), The political economy of flexicurity. FEDEA discussion paper 2006-15.

Booth, A. L. (1995). The economics of the trade union. Cambridge: Cambridge University Press.

Botero, J., Djankov, S., La Porta, R., Lopez-de-Silanes, \& Shleifer, A. (2004). The regulation of labor. The Quarterly Journal of Economics, 119(4), 1339-1382.

Boulhol, H. (2009). Do capital market and trade liberalization trigger labor market deregulation? Journal of International Economics, 77(2), 223-233.

Cusack, T. R. (1999). Some political data for 20 OECD countries. Berlin: WZB.

Disney, R. (2004). Are contributions to public pensions programmes a tax on employment? Economic Policy, $39,267-311$.

Di Tella, R., \& MacCulloch, R. (2002). The determination of unemployment benefits Journal of Labor Economics, 20(2), 404-434.

Du Caju, P., Gautier, E., Momferatou, D., \& Ward-Warmedinger, M. (2008). Institutional features of wage bargaining in 23 European countries, the US and Japan. IZA discussion paper No. 3867.

Dur, R. (2001). Wage-setting institutions, unemployment, and voters' demand for redistribution policy. Scottish Journal of Political Economy, 48(5), 517-531.

Eichhorst, W., Grienberger-Zingerle, M., \& Konle-Seidl, R. (2006). Activation policies in Germany: from status protection to basic income support. IZA discussion paper No. 2514.

European Commission (2008). Industrial relations in Europe 2008, Brussels.

Gaston, N., \& Nelson, D. (2004). Structural change and the labor-market effects of globalization. Review of International Economics, 12(5), 769-792.

Gaston, N., \& Rajaguru, G. (2008). The rise (and fall) of labour market programmes: domestic vs. global factors. Oxford Economic Papers, 60(4), 619-648.

Goerke, L. (2001). Bismarck versus Beveridge. Finanzarchiv, 57(3), 243-260.

Goerke, L., \& Madsen, J. B. (2003). Earnings-related unemployment benefit and unemployment. Economic Systems, 27(1), 41-62.

Golden, M., \& Wallerstein, M. (2004). Union centralization among advanced industrial societies: update to 1995/2000, Version 3.1, 7/28/2004

Hassler, J.M., Rodríguez, J. V., Kietil, S., \& Zilibotti, F. (2005). A positive theory of geographic mobility and social insurance. International Economic Review, 46(1), 263-303.

Heer, B. (2006). Should unemployment benefit be related to previous earnings? Finanzarchiv, 62(4), 530550. 
Heer, B., \& Morgenstern, A. (2005). The labor market effects of indexing unemployment benefit to previous earnings. Public Finance Review, 33(3), 385-402.

Howell, D. R., \& Rehm, M. (2009). Unemployment compensation and high European unemployment: a reassessment with new benefi indicators. Oxford Review of Economic Policy, 25(1), 60-93.

Lingens, J., \& Wälde, K. (2009). Pareto-improving unemployment policies. FinanzArchiv/Public Finance Analysis, 65(2), 220-245.

Martin, J. P. (1996). Measures of replacement rates for the purpose of international comparisons: a note. OECD Economic Studies, 26, 99-115.

Neugart, M. (2005). Unemployment insurance: the role of electoral systems and regional labor markets. European Journal of Political Economy, 21(4), 815-829.

Neugart, M. (2008). The choice of insurance in the labor market. Public Choice, 134(3-4), 445-462.

Nickell, S. J., \& Nunziata, L. (2001). Labour market institutions database (LMIDB), Version 2.0.

OECD (2004). Wage setting institutions and outcomes. In Employment outlook (pp. 127-181). Paris.

OECD (2007). Benefits and wages 2007-OECD indicators. Paris.

Oswald, A. J. (1982). The microeconomic theory of trade unions. The Economic Journal, 92(367), 576-595.

Oswald, A. J. (1993). Efficien contracts are on the labour demand curve: theory and evidence. Labour Economics, 1(1), 85-113.

Pallage, S., \& Zimmermann, C. (2001). Voting on unemployment insurance. International Economic Review, 42(4), 903-923.

Pencavel, J. H. (1991). Labor markets under trade unionism. Oxford: Blackwell.

Plümper, T., \& Troeger, V. E. (2007). Efficien estimation of time-invariant and rarely changing variables in finit sample panel analyses with unit fi ed effects. Political Analysis, 15(2), 124-139.

Potrafke, N. (2009). Labor market deregulation and globalization: empirical evidence from OECD countries. Review of World Economics (forthcoming).

Rothschild, K. W. (1986). 'Left' and 'Right' in 'Federal Europe'. Kyklos, 39, 359-376.

Saint-Paul, G. (1996). Exploring the political economy of labour market institutions. Economic Policy, 11, $265-315$.

Uusitalo, R., \& Verho, J. (2007). The effects of unemployment benefits on re-employment rates: evidence from the Finnish UI-benefit reform. IFAU working paper 21.

Vaubel, R. (2008). The political economy of labor market regulation by the European union. Review of International Organizations, 3(4), 435-465.

Vijlbrief, H., \& van de Wijngaert, R. (1995). Unemployment insurance policy and union wage formation. Labour, 9(2), 233-251.

Visser, J. (2009). The ICTWSS database, Amsterdam. http://www.uva-aias.net/207.

Wooldridge, J. M. (2002). Econometric analysis of cross section and panel data. Cambridge: MIT Press.

Wright, R. (1986). The redistributive roles of unemployment insurance and the dynamics of voting. Journal of Public Economics, 31(3), 377-399. 